\title{
Soil Methanotrophy Model (MeMo v1.0): a process-based model to quantify global uptake of atmospheric methane by soil
}

\author{
Fabiola Murguia-Flores ${ }^{1}$, Sandra Arndt ${ }^{1, \text { a }}$, Anita L. Ganesan ${ }^{1}$, Guillermo Murray-Tortarolo ${ }^{2}$, and \\ Edward R. C. Hornibrook ${ }^{3, b}$ \\ ${ }^{1}$ School of Geographical Sciences, University of Bristol, Bristol, BS8 1SS, UK \\ ${ }^{2}$ Catedra CONACyT comisionado al Instituto de Investigaciones en Ecosistemas y Sustentabilidad, Universidad Nacional \\ Autonoma de Mexico, Morelia, Mexico \\ ${ }^{3}$ School of Earth Sciences, University of Bristol, Bristol, BS8 1RJ, UK \\ ${ }^{a}$ current address: Department of Geosciences, Environment and Society, Université Libre de Bruxelles, Brussels, Belgium \\ b current address: Earth, Environmental and Geographic Sciences, The University of British Columbia, \\ Okanagan Campus, Kelowna, BC, V1V 1V7, Canada
}

Correspondence: Fabiola Murguia-Flores (fmurguia84@gmail.com)

Received: 20 May 2017 - Discussion started: 30 May 2017

Revised: 26 March 2018 - Accepted: 7 May 2018 - Published: 4 June 2018

\begin{abstract}
Soil bacteria known as methanotrophs are the sole biological sink for atmospheric methane $\left(\mathrm{CH}_{4}\right)$, a potent greenhouse gas that is responsible for $\sim 20 \%$ of the humandriven increase in radiative forcing since pre-industrial times. Soil methanotrophy is controlled by a plethora of factors, including temperature, soil texture, moisture and nitrogen content, resulting in spatially and temporally heterogeneous rates of soil methanotrophy. As a consequence, the exact magnitude of the global soil sink, as well as its temporal and spatial variability, remains poorly constrained. We developed a process-based model (Methanotrophy Model; MeMo v1.0) to simulate and quantify the uptake of atmospheric $\mathrm{CH}_{4}$ by soils at the global scale. MeMo builds on previous models by Ridgwell et al. (1999) and Curry (2007) by introducing several advances, including (1) a general analytical solution of the one-dimensional diffusion-reaction equation in porous media, (2) a refined representation of nitrogen inhibition on soil methanotrophy, (3) updated factors governing the influence of soil moisture and temperature on $\mathrm{CH}_{4}$ oxidation rates and (4) the ability to evaluate the impact of autochthonous soil $\mathrm{CH}_{4}$ sources on uptake of atmospheric $\mathrm{CH}_{4}$. We show that the improved structural and parametric representation of key drivers of soil methanotrophy in MeMo results in a better fit to observational data. A global simulation of soil methanotrophy for the period 1990-2009 using MeMo yielded an average annual sink of
\end{abstract}

$33.5 \pm 0.6 \mathrm{Tg} \mathrm{CH}_{4} \mathrm{yr}^{-1}$. Warm and semi-arid regions (tropical deciduous forest and open shrubland) had the highest $\mathrm{CH}_{4}$ uptake rates of 602 and $518 \mathrm{mg} \mathrm{CH}_{4} \mathrm{~m}^{-2} \mathrm{yr}^{-1}$, respectively. In these regions, favourable annual soil moisture content ( $\sim 20 \%$ saturation) and low seasonal temperature variations (variations $<\sim 6^{\circ} \mathrm{C}$ ) provided optimal conditions for soil methanotrophy and soil-atmosphere gas exchange. In contrast to previous model analyses, but in agreement with recent observational data, MeMo predicted low fluxes in wet tropical regions because of refinements in formulation of the influence of excess soil moisture on methanotrophy. Tundra and mixed forest had the lowest simulated $\mathrm{CH}_{4}$ uptake rates of 176 and $182 \mathrm{mgCH}_{4} \mathrm{~m}^{-2} \mathrm{yr}^{-1}$, respectively, due to their marked seasonality driven by temperature. Global soil uptake of atmospheric $\mathrm{CH}_{4}$ was decreased by $4 \%$ by the effect of nitrogen inputs to the system; however, the direct addition of fertilizers attenuated the flux by $72 \%$ in regions with high agricultural intensity (i.e. China, India and Europe) and by $4-10 \%$ in agriculture areas receiving low rates of $\mathrm{N}$ input (e.g. South America). Globally, nitrogen inputs reduced soil uptake of atmospheric $\mathrm{CH}_{4}$ by $1.38 \mathrm{Tg} \mathrm{yr}^{-1}$, which is $2-$ 5 times smaller than reported previously. In addition to improved characterization of the contemporary soil sink for atmospheric $\mathrm{CH}_{4}$, MeMo provides an opportunity to quantify more accurately the relative importance of soil methanotrophy in the global $\mathrm{CH}_{4}$ cycle in the past and its capacity to 
contribute to reduction of atmospheric $\mathrm{CH}_{4}$ levels under future global change scenarios.

\section{Introduction}

Methane $\left(\mathrm{CH}_{4}\right)$ is the most abundant organic trace gas in the atmosphere and responsible for approximately $20 \%$ of the human-driven increase in radiative forcing since preindustrial times (Myhre et al., 1998; Ciais et al., 2013). Anthropogenic activities during the last 200 years have increased the concentration of $\mathrm{CH}_{4}$ in the atmosphere from pre-industrial era levels of approximately 710 parts per billion $(\mathrm{ppb})$ to the current mixing ratio of approximately 1800 ppb (Etheridge et al., 1998; Kirschke et al., 2013). The atmospheric lifetime of $\mathrm{CH}_{4}$ is $9.1 \pm 0.9$ years (Prather et al., 2012) and most $\mathrm{CH}_{4}$ is consumed in the troposphere via oxidation by $\mathrm{OH}$ radicals, which represents $\sim 90 \%$ of the global $\mathrm{CH}_{4}$ sink (Prather et al., 2012; Ciais et al., 2013). Soil bacteria known as methanotrophs consume $\sim 9$ to $10 \%$ of atmospheric $\mathrm{CH}_{4}$ and a further $\sim 1 \%$ is oxidized by reaction with chlorine radicals from sea salt in the marine boundary layer (Allan et al., 2007; Ciais et al., 2013).

Soil methanotrophy is the only biological sink for $\mathrm{CH}_{4}$ and its rate is highly dependent on environmental conditions. The total global soil sink is similar in size to global emissions of $\mathrm{CH}_{4}$ from rice paddies (Kirschke et al., 2013), and consequently, year-to-year changes in factors that impact rates of soil $\mathrm{CH}_{4}$ oxidation may contribute to variability in the interannual growth rate of atmospheric $\mathrm{CH}_{4}$. Moreover, soil methanotrophy consumes up to $90 \%$ of $\mathrm{CH}_{4}$ produced via methanogenesis in persistently or periodically wet soil and thus factors that impact soil uptake of atmospheric $\mathrm{CH}_{4}$ may reduce the capacity of soil methanotrophs to attenuate emission of soil-produced $\mathrm{CH}_{4}$ (Oremland and Culbertson, 1992; Singh et al., 2010).

The rate of methanotrophy in soil is controlled by several environmental factors including temperature, soil texture, moisture and nitrogen (N) content (Czepiel et al., 1995; Le Mer and Roger, 2001; Wang et al., 2005). The influence of these factors on rates of $\mathrm{CH}_{4}$ oxidation has been widely studied both at the ecosystem level and under laboratory conditions. Positive correlations have been consistently reported between temperature and rates of $\mathrm{CH}_{4}$ oxidation in soil (Castro et al., 1995; Butterbach-Bahl and Papen, 2002; Rosenkranz et al., 2006; Luo et al., 2013). Atypically low and high soil moisture levels both have a negative impact on rates of atmospheric $\mathrm{CH}_{4}$ consumption. A soil moisture content of $\sim 20 \%$ appears to yield optimum rates of $\mathrm{CH}_{4}$ uptake in different ecosystems, including tropical forests, shortgrass steppe and tundra (Adamsen and King, 1993; Mosier et al., 2002; Burke et al., 1999; Castro et al., 1995; Epstein et al., 1998; Klemedtsson and Klemedtsson, 1997; McLain and Ahmann, 2007; West et al., 1999). Soil texture impacts the ability of soil to retain water and influences diffusion of atmospheric $\mathrm{CH}_{4}$ and $\mathrm{O}_{2}$ into soil because of its control on pore size and connectivity. Thus, sandy soil generally exhibits higher rates of $\mathrm{CH}_{4}$ uptake than silt-rich soil followed by clayey soil (Born et al., 1990; Dörr et al., 1993). The influence of $\mathrm{N}$ input from atmospheric deposition and fertilizer application is more complex; however, the majority of studies report inhibition of soil methanotrophy with increased addition of N (Aronson and Helliker, 2010; Bodelier and Laanbroek, 2004; Fang et al., 2014).

There is a large interannual variability and uncertainty in the accounting of the global $\mathrm{CH}_{4}$ budget, particularly for processes that consume $\mathrm{CH}_{4}$ (Kirschke et al., 2013). Our understanding of the main drivers of $\mathrm{CH}_{4}$ uptake in soils and how those factors respond to climate change is incomplete. Estimates of the soil $\mathrm{CH}_{4}$ sink based upon field data (Dutaur and Verchot, 2007) show high variability globally and within different ecosystems. Numerical models provide an efficient means to deal with the spatial and temporal heterogeneity and to evaluate mechanistic understanding of physical and biological processes that influence soil methanotrophy. Ultimately, models enable derivation of regional and global estimates of soil uptake of atmospheric $\mathrm{CH}_{4}$ and provide the ability to predict the response of soil methanotrophy to past and future global change. In addition, they provide a platform of interdisciplinary knowledge synthesis, help identify the most important parameters and environmental controls, and can thus inform future field and laboratory research.

Several detailed biogeochemical models have been developed to quantify consumption of atmospheric $\mathrm{CH}_{4}$ by soil. Saggar et al. (2007) produced a modified version (the denitrification-decomposition model for New Zealand - NZDNDC) of DNDC ( $\mathrm{Li}$ et al., 2000) to evaluate local impacts of changes in climate, soil properties, fertilizer management and grazing regimes on soil methanotrophy. Sabrekov et al. (2016) developed a process-based model of soil $\mathrm{CH}_{4}$ uptake that also incorporates rhizosphere methanotrophy. Oh et al. (2016) developed a model (XHAM) that explicitly simulates high-affinity methanotrophy and active microbial biomass dynamics. These models are driven by highresolution local data sets, which presents challenges for conducting global simulations of soil methanotrophy because of limited availability of input data necessary to drive the models (e.g. global rhizosphere depth, specific soil management, specific metabolic data and enzyme concentrations).

Previous global models included Potter et al. (1996) (hereafter referred to as the "P96" model), which estimates terrestrial uptake of $\mathrm{CH}_{4}$ by calculating diffusive flux of atmospheric $\mathrm{CH}_{4}$ into soil using a modified version of Fick's first law. Ridgwell et al. (1999) (hereafter referred to as the "R99" model) improved the P96 model by explicitly accounting for microbial $\mathrm{CH}_{4}$ oxidation in soil. The $\mathrm{R} 99$ model quantifies $\mathrm{CH}_{4}$ oxidation rates as a function of soil temperature, moisture and $\mathrm{N}$ content. The latter parameter was estimated using agricultural land area as a proxy for fertilizer appli- 
cation. Solution of the resulting one-dimensional diffusionreaction equation was approximated semi-numerically assuming steady-state conditions. Curry (2007) (hereafter referred to as the "C07" model) employed a steady-state analytical solution of the one-dimensional diffusion-reaction equation and introduced a scalar modifier to account for the regulation of $\mathrm{CH}_{4}$ oxidation rates by soil moisture and the impact of temperature below $0{ }^{\circ} \mathrm{C}$. The $\mathrm{C} 07$ model continued to use the R99 agricultural land area approximation to evaluate the effect of $\mathrm{N}$ loading on $\mathrm{CH}_{4}$ uptake. The $\mathrm{C} 07$ model has been employed as a reference model for the Global Carbon Project (Saunois et al., 2016) and has been used to estimate global $\mathrm{CH}_{4}$ uptake in dynamic global vegetation models, such as the Lund-Potsdam-Jena model (LPJ-WHyMe; Wania et al., 2010; Spahni et al., 2011).

The model of Zhuang et al. (2013) (hereafter referred to as model "Z13") employs the same steady-state diffusionreaction equation for $\mathrm{CH}_{4}$ as previous models; however, Z13 solves the steady-state diffusion-reaction equation for $\mathrm{CH}_{4}$ numerically using multiple soil layers. Additionally, parameterization of microbial activity in model Z13 is based upon redox potential, ecosystem-specific inputs for $Q_{10}$ and optimum soil moisture, and maximum rates of $\mathrm{CH}_{4}$ consumption instead of a base rate for $\mathrm{CH}_{4}$ oxidation. Consequently, model Z13 operates within the Terrestrial Ecosystem Model (TEM) that provides the necessary driving data because global data sets for many of these parameters are not available. If external data were available, model Z13 presumably could be operated independently of the TEM in a manner similar to the P96, R99 and C07 models. However, such a stand-alone application (i.e. decoupled from TEM) would require a new implementation or presumably significant modifications to the code.

We have chosen to focus on refining the R99 and C07 models because availability of new observational and experimental data presents an opportunity to re-evaluate global simulations of soil methanotrophy based upon an enhanced version of these models. For example, new global data sets quantifying $\mathrm{N}$ deposition and $\mathrm{N}$ input via fertilizers now enable better representation of this inhibitory effect on soil uptake of atmospheric $\mathrm{CH}_{4}$ (Lamarque et al., 2013). In addition, a new global inventory of $\mathrm{CH}_{4}$ uptake rates in soil (Dutaur and Verchot, 2007) provides a means to better compare and validate model simulations.

Here, we present an updated process-based model to quantity the global sink for atmospheric $\mathrm{CH}_{4}$ by soil (hereafter referred to as "MeMo": soil Methanotrophy Model). MeMo is based on a general analytical solution of the one-dimensional diffusion-reaction equation, which makes obsolete the a priori assumption of complete $\mathrm{CH}_{4}$ consumption in the model domain applied in the $\mathrm{C} 07$ model. The refinement now also provides the opportunity to account for $\mathrm{CH}_{4}$ flux from below (i.e. due to $\mathrm{CH}_{4}$ production in soil, if present) and to set a minimum methane concentration threshold at which methanotrophy can occur in the soil column. In addition, MeMo re- visits and improves R99 and C07 model formulations to incorporate advances in the mechanistic understanding of soil methanotrophy that have resulted from availability of new data. Finally, MeMo utilizes for the first time data for atmospheric $\mathrm{N}$ deposition and $\mathrm{N}$ input from fertilizers to explore more accurately the effect of land use and land-use changes on the global $\mathrm{CH}_{4}$ sink. We present a comprehensive description of the new model, a comparison of MeMo with the R99 and C07 models, and a critical discussion of model formulations and assumptions based on observational data. We then provide an assessment of global and regional soil uptake and variability across ecosystem types and seasons.

\section{Model description}

The following sections provide a detailed description of MeMo in the context of existing global soil $\mathrm{CH}_{4}$ uptake. Table 1 provides a summary of all terms, names and units used in the model description section, while Table 2 contains a short summary of the four global $\mathrm{CH}_{4}$ uptake models based on the P96 family.

\subsection{Conservation equation}

The general, one-dimensional mass conservation equation for $\mathrm{CH}_{4}$ in soil is given by

$$
\frac{\partial \mathrm{CH}_{4}}{\partial t}=-\frac{\partial J_{\mathrm{CH}_{4}}}{\partial_{z}}+\sum R,
$$

where $J_{\mathrm{CH}_{4}}$ denotes the flux of $\mathrm{CH}_{4}$ and $\Sigma R$ is the sum of all production and consumption processes that affect $\mathrm{CH}_{4}$ concentrations in soil. The flux $J_{\mathrm{CH}_{4}}$ in the soil is generally controlled by diffusion. Consequently, the P96 model assumes that global uptake of atmospheric $\mathrm{CH}_{4}$ by soil is diffusion limited and thus describes the soil $\mathrm{CH}_{4}$ sink as a purely diffusive process (i.e. $\sum R=0$ ). However, $\mathrm{CH}_{4}$ is consumed by microbial activity in the soil and the simplified diffusion model may thus underestimate total uptake of $\mathrm{CH}_{4}$. Consequently, R99 extended the diffusion model by explicitly accounting for microbial oxidation of $\mathrm{CH}_{4}$ through a firstorder rate expression. The resulting diffusion-reaction equation forms the basis of the R99 model, the C07 model and MeMo:

$$
\frac{\partial \mathrm{CH}_{4}}{\partial t}=-D_{\mathrm{CH}_{4}} \frac{\partial^{2} \mathrm{CH}_{4}}{\partial z^{2}}+k_{d} \times \mathrm{CH}_{4},
$$

where $D_{\mathrm{CH}_{4}}$ is the $\mathrm{CH}_{4}$ diffusion coefficient and $k_{d}$ the first-order rate constant for microbial $\mathrm{CH}_{4}$ oxidation. Under steady-state conditions (i.e. $\partial \mathrm{CH}_{4} / \partial t=0$ ), soil $\mathrm{CH}_{4}$ uptake is controlled by the balance between diffusion of $\mathrm{CH}_{4}$ into soil and the rate of microbial $\mathrm{CH}_{4}$ oxidation. Hence, accurate characterization of $D_{\mathrm{CH}_{4}}$ and $k_{d}$ is essential for a robust quantification of $\mathrm{CH}_{4}$ uptake by soil. 
Table 1. Terms, names and units used in the model description section.

\begin{tabular}{|c|c|c|}
\hline Terms & Name & Units \\
\hline $\mathrm{CH}_{4}$ & $\mathrm{CH}_{4}$ concentration & $\mathrm{mg} \mathrm{m}^{-3}$ \\
\hline$J_{\mathrm{CH}_{4}}$ & $\mathrm{CH}_{4}$ flux uptake & $\mathrm{mg} \mathrm{CH}_{4} \mathrm{~m}^{-2}$ month $^{-1}$ \\
\hline $\mathrm{C}_{\mathrm{CH}_{4}}$ & Atmospheric $\mathrm{CH}_{4}$ concentration & $\mathrm{ppb}$ \\
\hline $\mathrm{CH}_{4}$ min & $\mathrm{CH}_{4}$ threshold & $\mathrm{ppb}$ \\
\hline $\mathrm{F}_{\mathrm{CH}_{4}}$ & $\mathrm{CH}_{4}$ flux through $L$ & $\mathrm{mg} \mathrm{CH}_{4} \mathrm{~m}^{-2}$ month $^{-1}$ \\
\hline$z$ & Depth in the soil profile & $\mathrm{cm}$ \\
\hline$L$ & Depth of $99.9 \%$ penetration of atmospheric $\mathrm{CH}_{4}$ into the soil & $\mathrm{cm}$ \\
\hline$D_{\mathrm{CH}_{4}}$ & Diffusion coefficient of $\mathrm{CH}_{4}$ into soil & $\mathrm{cm}^{2} \mathrm{~s}^{-1}$ \\
\hline$k_{d}$ & $\mathrm{CH}_{4}$ oxidation activity & $s^{-1}$ \\
\hline$D_{0 \mathrm{CH}_{4}}=0.196$ & $\begin{array}{l}\mathrm{CH}_{4} \text { diffusion in free air at standard temperature and } \\
\text { pressure (STP) of } 0^{\circ} \mathrm{C} \text { and } 1 \mathrm{~atm} \text { pressure }\end{array}$ & $\mathrm{cm}^{2} \mathrm{~s}^{-1}$ \\
\hline$G_{\mathrm{T}}$ & Soil temperature response & ${ }^{\circ} \mathrm{C}$ \\
\hline$G_{\text {soil }}$ & Soil structure response & dimensionless \\
\hline$\Phi$ & Total pore volume & $\mathrm{cm}^{3} \mathrm{~cm}^{-3}$ \\
\hline$\rho$ & Bulk density & $\mathrm{cm}^{-3} \mathrm{~g}^{-1}$ \\
\hline$d=2.65$ & Soil particle density & $\mathrm{g} \mathrm{cm}^{-3}$ \\
\hline$\Phi_{\text {air }}$ & Air-filled porosity & $\mathrm{cm}^{3} \mathrm{~cm}^{-3}$ \\
\hline$\theta$ & Soil water content & $\%$ \\
\hline$w$ & Saturation soil water potential & $\mathrm{MPa}$ \\
\hline$b$ & Clay soil content factor & dimensionless \\
\hline$f_{\text {clay }}$ & Clay soil content & $\%$ \\
\hline$k_{0}$ & Base oxidation rate constant for uncultivated moist soil at $0^{\circ} \mathrm{C}$ & $\mathrm{s}^{-1}$ \\
\hline$r_{\mathrm{SM}}$ & Microbial $\mathrm{CH}_{4}$ oxidation, soil moisture response & dimensionless \\
\hline$r_{\mathrm{T}}$ & Microbial $\mathrm{CH}_{4}$ oxidation, temperature response & dimensionless \\
\hline$r_{\mathrm{N}}$ & Microbial $\mathrm{CH}_{4}$ oxidation, nitrogen response & dimensionless \\
\hline$N_{\text {soil }}$ & Nitrogen deposition into soil & $\mathrm{g} \mathrm{N} \mathrm{m}^{-2}$ month $^{-1}$ \\
\hline$\alpha=0.33$ & Average coefficient of $\mathrm{N}$ deposition inhibition & $\% \mathrm{~mol} \mathrm{~N}^{-1}$ \\
\hline
\end{tabular}

\subsection{Solution of the reaction-transport equation}

The R99 model solved Eq. (2) semi-numerically by (i) assuming steady state, (ii) numerically approximating the diffusion term similar to the approach applied in the P96 model (Table 2, Eq. 11) and (iii) assigning $\mathrm{CH}_{4}$ oxidation exclusively to a distinct soil layer of thickness $\epsilon$ at depth $z_{d}=6 \mathrm{~cm}$ (Table 2, Eq. 12). However, $\mathrm{CH}_{4}$ consumption can occur throughout a soil profile, and thus Eq. (12) (Table 2) may either overestimate or underestimate the $\mathrm{CH}_{4}$ sink.

In the C07 model, Eq. (2) was solved analytically, providing a more accurate and mathematically robust estimate of $\mathrm{CH}_{4}$ uptake (Table 2, Eq. 13). Assuming steady-state conditions and constant $D_{\mathrm{CH}_{4}}$ and $k_{d}$ throughout the soil profile, integration of Eq. (2) provides a general solution for determining $\mathrm{CH}_{4}$ concentration at depth $z$ in soil:

$\mathrm{CH}_{4}(z)=A \times \exp \left(-\sqrt{\frac{k_{d}}{D_{\mathrm{CH}_{4}}} z}\right)+B \exp \left(\sqrt{\frac{k_{d}}{D_{\mathrm{CH}_{4}}} z}\right)$,

where $A$ and $B$ are integration constants that can be determined by setting upper and lower boundary conditions for the soil profile. The concentration of $\mathrm{CH}_{4}$ at the soil-atmosphere interface is defined by the atmospheric concentration of $\mathrm{CH}_{4}$
$\left(C_{\mathrm{CH}_{4}}\right)$, and thus a Dirichlet boundary (i.e. fixed concentration) is applied at the upper boundary. Conditions at the lower boundary are more challenging to ascribe because the soil depth at which atmospheric $\mathrm{CH}_{4}$ is completely consumed is not known a priori.

\subsubsection{Negligible $\mathrm{CH}_{4}$ flux through the lower boundary (C07 solution)}

The C07 model circumvents the problem by applying a homogenous Neumann (no-flux) condition at the lower model boundary: $\left.\frac{\mathrm{dCH}_{4}}{\mathrm{~d} z}\right|_{z \rightarrow \infty}=0$.

The application of this boundary condition allows derivation of the integration constants $A=C_{\mathrm{CH}_{4}}$ and $B=0$, which simplifies Eq. (3) to

$\mathrm{CH}_{4}(z)=C_{\mathrm{CH}_{4}} \times \exp \left(-\sqrt{\frac{k_{d}}{D_{\mathrm{CH}_{4}}}} \times z\right)$.

The diffusive uptake of atmospheric $\mathrm{CH}_{4}$ at the soilatmosphere interface can then be calculated using the deriva- 
Table 2. Descriptions of four soil methanotrophy models.

\begin{tabular}{|c|c|c|c|}
\hline Model/study & Description & $\mathrm{CH}_{4}$ uptake calculation $\left(\mathrm{J}_{\mathrm{CH}_{4}}\right)$ & Eq. \\
\hline $\begin{array}{l}\text { P96 } \\
\text { Potter et } \\
\text { al. (1996) }\end{array}$ & $\begin{array}{l}\text { P96 is the model based on Fick's first law. The calcula- } \\
\text { tion of the uptake flux is approximated numerically and } \\
\text { based on the diffusion of } \mathrm{CH}_{4} \text { into soil. }\end{array}$ & $J_{\mathrm{CH}_{4}}=D_{\mathrm{CH}_{4}} \frac{\Delta C_{\mathrm{CH}_{4}}}{\Delta_{z}}$ & (11) \\
\hline $\begin{array}{l}\text { R99 } \\
\text { Ridgwell et } \\
\text { al. (1999) }\end{array}$ & $\begin{array}{l}\mathrm{R} 99 \text { extends the P96 model by including an explicit } \\
\text { term for microbial oxidation of } \mathrm{CH}_{4} \text { in soil. The up- } \\
\text { take flux is approximated numerically, using Fick's first } \\
\text { law and adopting a first-order rate law for microbial ox- } \\
\text { idation, assuming that oxidation occurs in a thin } \epsilon \mathrm{cm} \\
\text { layer located at } 6 \mathrm{~cm} \text { depth. }\end{array}$ & $J_{\mathrm{CH}_{4}}=\frac{C_{\mathrm{CH}_{4}} D_{\mathrm{CH}_{4}}}{z_{d}}\left(1-\frac{D_{\mathrm{CH}_{4}}}{D_{\mathrm{CH}_{4}}+k_{d} z_{d}}\right)$ & (12) \\
\hline $\begin{array}{l}\text { C07 } \\
\text { Curry (2007) }\end{array}$ & $\begin{array}{l}\text { C } 07 \text { adopts the diffusion-reaction equation that under- } \\
\text { lies R99. However, } \mathrm{C} 07 \text { solves the equation analytically } \\
\text { (as opposed to semi-numerically). The model also im- } \\
\text { proves representation of soil moisture influence on the } \\
\text { microbial oxidation rate. C } 07 \text { refines methanotrophy re- } \\
\text { sponse at subzero temperatures on the basis of observa- } \\
\text { tions. }\end{array}$ & $J_{\mathrm{CH}_{4}}=C_{\mathrm{CH}_{4}} r_{\mathrm{N}} r_{w} \sqrt{D_{\mathrm{CH}_{4}} k} d$ & (13) \\
\hline $\begin{array}{l}\text { MeMo } \\
\text { This study }\end{array}$ & $\begin{array}{l}\text { This study incorporates a general mathematical descrip- } \\
\text { tion of } \mathrm{CH}_{4} \text { uptake flux, allowing for complete con- } \\
\text { sumption of } \mathrm{CH}_{4} \text { at an initially unknown depth } L \text { and } \\
\mathrm{CH}_{4} \text { flux through the lower boundary. Refines represen- } \\
\text { tation of the influence of soil moisture, temperature and } \\
\text { nitrogen deposition on } \mathrm{CH}_{4} \text { oxidation. }\end{array}$ & $J_{\mathrm{CH}_{4}}=-D_{\mathrm{CH}_{4}}\left(-A \sqrt{\frac{k_{d}}{D_{\mathrm{CH}_{4}}}}+B \sqrt{\frac{k_{d}}{D_{\mathrm{CH}_{4}}}}\right)$ & (10) \\
\hline
\end{tabular}

tive of Eq. (4) at $z=0$ :

$$
\begin{aligned}
J_{\mathrm{CH}_{4}} & =-D_{\mathrm{CH}_{4}} \times\left.\frac{\mathrm{dCH}}{\mathrm{d} z}\right|_{z=0} \\
& =D_{\mathrm{CH}_{4}} \times C_{\mathrm{CH}_{4}} \times \sqrt{\frac{k_{d}}{D_{\mathrm{CH}_{4}}}} \\
& =C_{\mathrm{CH}_{4}} \sqrt{D_{\mathrm{CH}_{4}} k_{d}} .
\end{aligned}
$$

This formulation of soil uptake of $\mathrm{CH}_{4}$ is the simplest analytical solution to Eq. (2). It represents an improvement from the semi-numerical representation used in the R99 model and enables complete consumption of $\mathrm{CH}_{4}$ to be accounted for within the soil; however, the homogeneous Neumann boundary condition applied here is only an approximation, which is not generally valid. The simulation will not be influenced if the Neumann boundary is infinitely far from the consumption depth of $\mathrm{CH}_{4}$, and thus the corresponding Neumann boundary condition can be neglected. However, if this is not the case, it will result in simulation error.

\subsubsection{Complete consumption of $\mathrm{CH}_{4}$ at an a priori unknown depth $L$ (MeMo solution)}

Therefore, we adopted an approach similar to the $\mathrm{C} 07$ model but one that is generally valid. We assume that methanotrophy consumes atmospheric $\mathrm{CH}_{4}$ in the soil until $\mathrm{CH}_{4}$ reaches a threshold $\left(\mathrm{CH}_{4}(L)=\mathrm{CH}_{4} \min \right)$ that can be imposed based on biological limits $\left(\mathrm{CH}_{4} \min =100 \mathrm{ppb}\right)$ or when $\mathrm{CH}_{4}$ is fully depleted $\left(\mathrm{CH}_{4} \min =0\right)$. The integration constants in Eq. (3) thus become

$$
\begin{aligned}
& A=-\frac{C_{\mathrm{CH}_{4}} \times \exp \left(\sqrt{\frac{k_{d}}{D_{\mathrm{CH}_{4}}}} L\right)-\mathrm{CH}_{4} \min }{\left[\exp \left(-\sqrt{\frac{k_{d}}{D_{\mathrm{CH}_{4}}}} L\right)-\exp \left(\sqrt{\frac{k_{d}}{D_{\mathrm{CH}_{4}}}} L\right)\right]} \\
& B=\frac{-\mathrm{CH}_{4} \min +C_{\mathrm{CH}_{4}} \times \exp \left(-\sqrt{\frac{k_{d}}{D_{\mathrm{CH}_{4}}}} L\right)}{\left[\exp \left(-\sqrt{\frac{k_{d}}{D_{\mathrm{CH}_{4}}}} L\right)-\exp \left(\sqrt{\frac{k_{d}}{D_{\mathrm{CH}_{4}}}} L\right)\right]} \text {. }
\end{aligned}
$$

In addition to the concentration condition $\mathrm{CH}_{4}(L)=\mathrm{CH}_{4}$ min, a flux condition also is imposed on the lower boundary in order to determine depth $L:-D_{\mathrm{CH}_{4}} \times\left.\frac{\mathrm{dCH}}{\mathrm{d} z}\right|_{z=L}=F_{\mathrm{CH}_{4}}$, where $\mathrm{F}_{\mathrm{CH}_{4}}$ denotes a potential $\mathrm{CH}_{4}$ flux across the lower boundary that can be specified (i.e. $\mathrm{CH}_{4}(L)=\mathrm{CH}_{4} \mathrm{~min}$ ) or set equal to zero (i.e. $\mathrm{CH}_{4}(L)=0$ ). The unknown depth $L$ is then calculated by substituting the derivative of Eq. (3) into the expression for the lower boundary condition: 


$$
\begin{aligned}
& -D_{\mathrm{CH}_{4}} \times\left.\frac{\mathrm{dCH}}{\mathrm{d} z}\right|_{L}= \\
& -D_{\mathrm{CH}_{4}} \times\left(A\left(-\sqrt{\frac{k_{d}}{D_{\mathrm{CH}_{4}}}}\right) \times \exp \left(-\sqrt{\frac{k_{d}}{D_{\mathrm{CH}_{4}}}} L\right)\right. \\
& \left.+B \sqrt{\frac{k_{d}}{D_{\mathrm{CH}_{4}}}} \times \exp \left(\sqrt{\frac{k_{d}}{D_{\mathrm{CH}_{4}}}} L\right)\right)=F_{\mathrm{CH}_{4}} .
\end{aligned}
$$

Rearranging Eq. (8) and finding its root allows for the determination of the initially unknown depth $L$ where $\mathrm{CH}_{4}(L)=$ $\mathrm{CH}_{4}$ min:

$$
\begin{aligned}
& 0=-D_{\mathrm{CH}_{4}} \sqrt{\frac{k_{d}}{D_{\mathrm{CH}_{4}}}}
\end{aligned}
$$

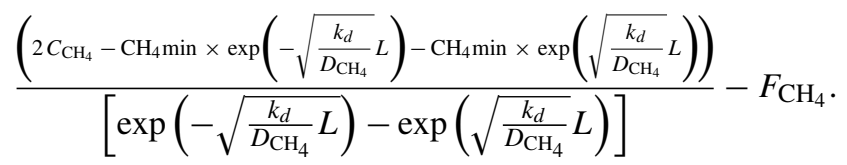

Once $L$ is known, total $\mathrm{CH}_{4}$ uptake can be calculated from

$$
\begin{aligned}
J_{\mathrm{CH}_{4}} & =-D_{\mathrm{CH}_{4}} \times\left.\frac{\mathrm{dCH}}{\mathrm{d} z}\right|_{z \rightarrow z}=0 \\
& =-D_{\mathrm{CH}_{4}}\left(-A \sqrt{\frac{k_{d}}{D_{\mathrm{CH}_{4}}}}+B \sqrt{\frac{k_{d}}{D_{\mathrm{CH}_{4}}}}\right),
\end{aligned}
$$

where $A$ and $B$ are defined by Eqs. (6) and (7). When $L$ tends to infinity, Eq. (10) is equivalent to the $\mathrm{C} 07$ model solution; however, Eq. (10) also allows for (i) complete consumption of $\mathrm{CH}_{4}$ within the soil interval, (ii) influx of $\mathrm{CH}_{4}$ from beneath the soil profile (e.g. from thawing permafrost or production of $\mathrm{CH}_{4}$ in oxygen-depleted microsites in soil) and (iii) a minimum $\mathrm{CH}_{4}$ concentration at which methanotrophy can occur in the soil column.

Figure 1 illustrates $\mathrm{CH}_{4}$ soil profiles and the penetration depth of $\mathrm{CH}_{4}$ into soil, $L$, for different $k_{d}$ values, $F_{\mathrm{CH}_{4}}=0$ and $D_{\mathrm{CH}_{4}}=D_{0 \mathrm{CH}_{4}}$ (diffusivity in free air) (Table 1). It is expected that $L$ will vary spatially depending on local $k_{d}$, $D_{\mathrm{CH}_{4}}$ and soil properties.

MeMo is based on the more general solution (Eq. 10) and uses local methanotrophy rates $\left(k_{d}\right)$ and diffusion coefficients $\left(D_{\mathrm{CH}_{4}}\right)$ based upon soil conditions to determine $\mathrm{CH}_{4}$ penetration depths $(L)$. Additionally, Eq. (9) allows one to set a minimum $\mathrm{CH}_{4}$ concentration if this parameter is known. Here, we assume a minimum of 0 or complete consumption. We assume no in situ production of $\mathrm{CH}_{4}$ or upward $\mathrm{CH}_{4}$ flux from below (i.e. $\mathrm{F}_{\mathrm{CH}_{4}}=0$ ) because of a scarcity of field data for model validation. However, a flux from below can be employed in MeMo to enable a more comprehensive quantification of soil $\mathrm{CH}_{4}$ uptake that also potentially accounts for consumption of upward-migrating $\mathrm{CH}_{4}$ and autochthonous $\mathrm{CH}_{4}$ produced in oxygen-depleted microsites of finely textured soil.

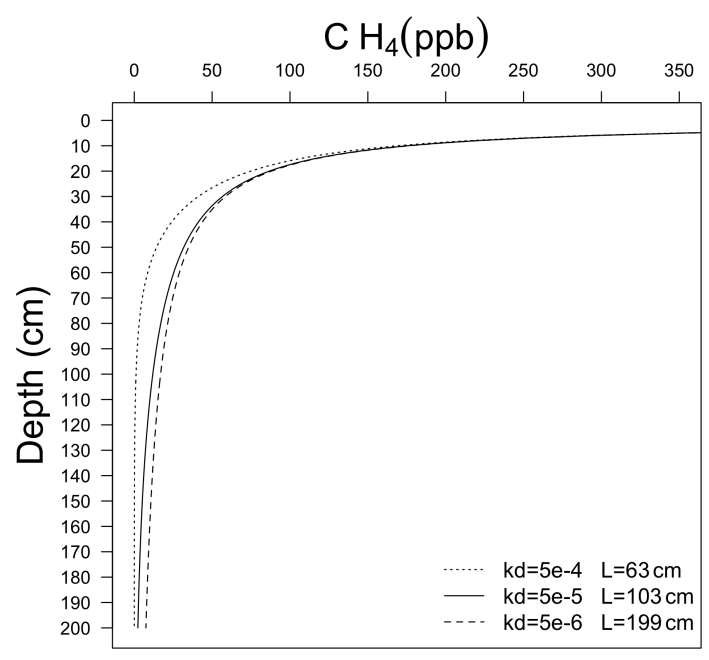

Figure 1. Computational solution of Eq. (9) for different values of $k_{d}$. Parameter $L$ is defined as the depth where $\mathrm{CH}_{4} \min =0$, assuming complete removal of $\mathrm{CH}_{4}$ in soil pore spaces.

\subsection{Parameters}

The rate of $\mathrm{CH}_{4}$ uptake by soil is controlled by the balance between gaseous diffusion of atmospheric $\mathrm{CH}_{4}$ into soil and the rate of $\mathrm{CH}_{4}$ oxidation by methanotrophic bacteria as described by Eqs. (14) and (20), respectively. Thus, $D_{\mathrm{CH}_{4}}$ and $k_{d}$ are key parameters, and accurate characterization of their values is essential for robust quantification of the soil $\mathrm{CH}_{4}$ sink.

\subsubsection{Soil $\mathrm{CH}_{4}$ diffusivity, $\mathrm{D}_{\mathrm{CH}_{4}}$}

Similar to the R99 and C07 models, $D_{\mathrm{CH}_{4}}$ in MeMo is determined from the diffusivity of $\mathrm{CH}_{4}$ in free air $\left(D_{0} \mathrm{CH}_{4}\right.$; Table 1$)$ adjusted for the influence of temperature $\left(G_{\mathrm{T}}\right)$ and soil structure $\left(G_{\text {soil }}\right)$ :

$D_{\mathrm{CH}_{4}}=D_{0 \mathrm{CH}_{4}} \times G_{\mathrm{T}} \times G_{\text {soil }}$.

The gaseous diffusion coefficient of $\mathrm{CH}_{4}$ in soil increases linearly with temperature $T\left({ }^{\circ} \mathrm{C}\right)$ (Potter et al., 1996) according to the relationship

$G_{\mathrm{T}}=1.0+0.0055 T\left({ }^{\circ} \mathrm{C}\right)$.

The soil structure factor $\left(G_{\text {soil }}\right)$ accounts for the effects of pore size, connectivity and tortuosity on gaseous diffusion and is determined according to the parameterization of Moldrup et al. $(1996,2013)$ :

$G_{\text {soil }}=\Phi^{4 / 3}\left(\frac{\Phi_{\text {air }}}{\Phi}\right)^{1.5+3 / b}$

where $\Phi$ is total pore volume $\left(\mathrm{cm}^{3} \mathrm{~cm}^{-3}\right), \Phi_{\text {air }}$ is air-filled porosity $\left(\mathrm{cm}^{3} \mathrm{~cm}^{-3}\right)$, and $b$ is a scalar that accounts for soil 
structure. Total pore volume is defined as a function of bulk density $\rho\left(\mathrm{g} \mathrm{cm}^{-3}\right)$ and average particle density $d$ (Table 1 ) (Brady et al., 1999):

$\Phi=1-\left(\frac{\rho}{d}\right)$.

The scalar $b$ in Eq. (16) is calculated as a function of soil clay content $\left(f_{\text {clay }} ; \%\right)$ as proposed by Saxton et al. (1986):

$b=15.9 f_{\text {clay }}+2.91$.

Air-filled porosity $\left(\Phi_{\text {air }}\right)$ is determined from the difference between total pore volume and soil water content $\theta(\%)$ :

$\Phi_{\text {air }}=\Phi-\theta$.

\subsubsection{Rate constant for $\mathrm{CH}_{4}$ oxidation, $k_{d}$}

The $\mathrm{CH}_{4}$ oxidation rate $\left(k_{d}\right)$ is defined as the base oxidation rate constant $\left(k_{0}\right)$ for an uncultivated moist soil at $0{ }^{\circ} \mathrm{C}$ scaled by three factors to account for the influence of soil moisture $\left(r_{\mathrm{SM}}\right)$, soil temperature $\left(r_{\mathrm{T}}\right)$ and nitrogen content $\left(r_{\mathrm{N}}\right)$ :

$k_{d}=k_{0} \times r_{\mathrm{SM}} \times r_{\mathrm{T}} \times r_{\mathrm{N}}$.

The R99 and C07 models used a similar equation to estimate $k_{d}$ but without the $r_{\mathrm{N}}$ parameter, opting instead to employ intensity of agricultural activity as a proxy to account for the inhibitory effects of $\mathrm{N}$ deposition on soil methanotrophy. Moreover, the $\mathrm{C} 07$ model excluded $r_{\mathrm{N}}$ from the $k_{d}$ formulation and used a $\mathrm{N}$ deposition term to modify total $\mathrm{CH}_{4}$ uptake flux (Table 2, Eq. 13), which results in a larger $\mathrm{N}$ inhibition effect. The approach employed in MeMo is to use $\mathrm{N}$ deposition data directly to modify $k_{d}$.

\subsubsection{Base oxidation rate constant, $k_{0}$}

The base oxidation rate constant $\left(k_{0}\right)$ is a key parameter that exerts significant control on $k_{d}$ and thus the estimated $\mathrm{CH}_{4}$ uptake flux. For example, a 10-fold change in $k_{0}$ (and thus $k_{d}$ ) leads to a 3 -fold decrease in the depth $L$ at which $\mathrm{CH}_{4}$ is fully depleted from soil pores (Fig. 1) and a $\sim 3$-fold increase in total uptake of $\mathrm{CH}_{4}$ (Fig. 2).

Rate constants can be defined either on the basis of theoretical considerations or through site-specific field and laboratory observations. Rates of soil microbial processes, such as $\mathrm{CH}_{4}$ oxidation, are controlled by microbial biomass dynamics and community structure, and thus a complex array of environmental factors, including temperature, substrate $\left(\mathrm{CH}_{4}\right)$ concentration, land use, moisture, $\mathrm{pH}$ and soil type (Ho et al., 2013). The influence of these environmental factors on microbial $\mathrm{CH}_{4}$ oxidation rates is not well characterized, and thus all factors are not explicitly represented in models. Consequently, apparent rate constants implicitly account for some environmental factors via fitting field observations or laboratory experiments, resulting in parameter values that may be more environment- and model-specific. A possible

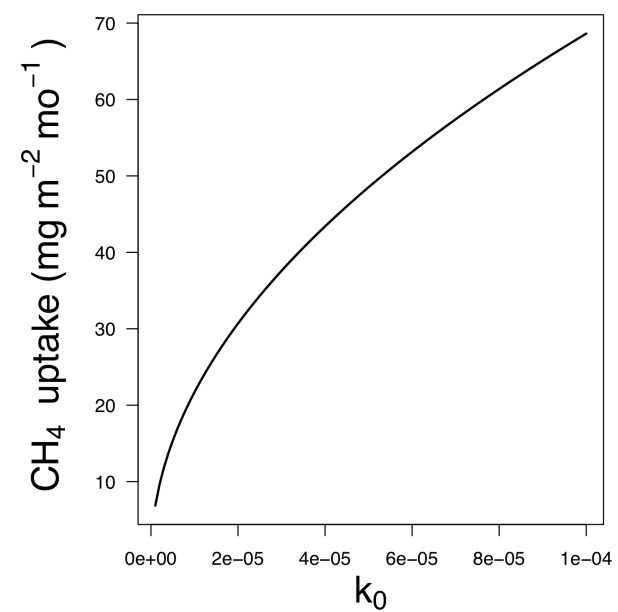

Figure 2. Total $\mathrm{CH}_{4}$ uptake for different values of $k_{0}\left(\mathrm{~s}^{-1}\right)$, assuming a constant value of $D_{\mathrm{CH}_{4}}=D_{0 \mathrm{CH}_{4}}$ and no modification by soil temperature, moisture or nitrogen deposition.

limitation of such an approach is reduced transferability and predictive capacity in other environments or from a regional to global scale. For example, Ridgwell et al. (1996) derived a single global estimate of $k_{0}=8.7 \times 10^{-4} \mathrm{~s}^{-1}$ by fitting Eq. (12) to 13 measured values of $J_{\mathrm{CH}_{4}}, D_{\mathrm{CH}_{4}}$ and soil temperature from four different studies. In contrast, Curry (2007) estimated a global $k_{0}$ of $5.0 \times 10^{-5} \mathrm{~s}^{-1}$ based upon fitting Eq. (13) to a 5-year time series of $J_{\mathrm{CH}_{4}}$ and soil temperature, moisture and $\mathrm{CH}_{4}$ flux measurements from a single site in Colorado (Mosier et al., 1996). The order of magnitude difference in $k_{0}$ between the R99 and C07 models illustrates the potential model-specific nature of parameter values derived from experimental and observational data, as well as the limits and challenges for transferability. Soil methanotrophy is not unique in this regard, and parameterization of microbially mediated processes remains a common problem more generally in modelling approaches (e.g. Arndt et al., 2013; Bradley et al., 2016).

Parameterization of $k_{0}$ in MeMo has been refined using time-series data recently published by Luo et al. (2013), which consist of daily soil $\mathrm{CH}_{4}$ uptake rates and temperature and soil moisture data from three contrasting environments: temperate forest (Höglwald, Germany), tropical rainforest (Bellenden Ker, Australia) and steppe (Inner Mongolia, China). The data sets were used to explore potential variations in apparent $k_{0}$ values in different environments, including comparison with $k_{0}$ values from the $\mathrm{R} 99$ and $\mathrm{C} 07$ models; however, the uncertainty of this value could not be characterized due to a dearth of available observational data. Data from each site were interpolated according to Eq. (10) to derive an apparent $k_{0}$ value for each biome. The $k_{0}$ values for temperate forest and steppe are similar to the $k_{0}$ value employed in the $\mathrm{C} 07$ model; however, the apparent $k_{0}$ for tropical forest is approximately 3 times smaller than the $\mathrm{C} 07$ model $k_{0}$ value. The three newly derived $k_{0}$ values were em- 

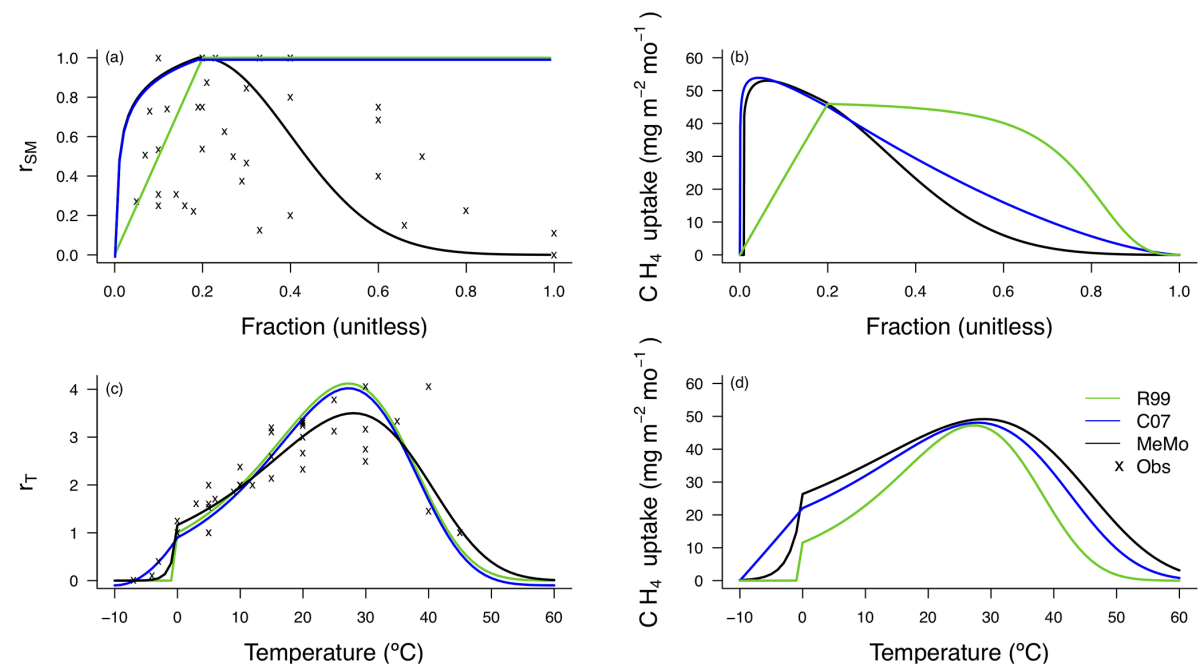

Figure 3. $\mathrm{CH}_{4}$ uptake response factors $(\mathbf{a}, \mathbf{c})$ and uptake fluxes $(\mathbf{b}, \mathbf{d})$ as a function of soil moisture $\left(r_{\mathrm{SM}}\right)$ and temperature $\left(r_{\mathrm{T}}\right)$. Observations (shown as crosses) ( $r_{\mathrm{SM}}$, File 1 in the Supplement, Table S1; $r_{\mathrm{T}}$, File 1 in the Supplement, Table S2), MeMo (black line), C07 (blue line) and R99 (green line).

Table 3. $k_{0}$ values from the R99 and C07 models, and new $k_{0}$ values employed in MeMo that were determined based upon temperate forest, tropical forest and steppe data from Luo et al. (2013).

\begin{tabular}{lll}
\hline Model & Biome & $k_{0}\left(\mathrm{~s}^{-1}\right)$ \\
\hline R99 & Global & $8.7 \times 10^{-4}$ \\
C07 & Global & $5.0 \times 10^{-5}$ \\
MeMo & Temperate forest & $4.0 \times 10^{-5}$ \\
& Tropical forest & $1.6 \times 10^{-5}$ \\
& Steppe & $3.6 \times 10^{-5}$ \\
& Other ecosystems & $5.0 \times 10^{-5}$ \\
\hline
\end{tabular}

ployed in MeMo for their respective biomes and the $k_{0}$ value from the C07 model $\left(k_{0}=5.0 \times 10^{-5} \mathrm{~s}^{-1}\right)$ was used for all other regions for which no biome-specific $k_{0}$ values exist (Table 3). Similar $k_{0}$ values of $5.0 \times 10^{-5} \mathrm{~s}^{-1}$ for temperate forest, steppe and short- grass steppe indicate that this magnitude of $k_{0}$ is appropriate for many ecosystems. Yet, apart from the tropical wet forest, the data clearly indicate additional controls and the use of $k_{0}=1.6 \times 10^{-5} \mathrm{~s}^{-1}$ will thus prevent an overestimation of simulated fluxes. Nevertheless, further research is required to better characterize this key parameter.

\subsubsection{Soil moisture factor, $r_{\mathrm{SM}}$}

Both low and high soil moisture levels can negatively impact soil uptake of atmospheric $\mathrm{CH}_{4}$ (Schnell and King, 1996; von Fischer et al., 2009). Scarcity of soil water generally inhibits soil microbial activity while excessive moisture attenuates gas diffusion, limiting entry of atmospheric $\mathrm{CH}_{4}$ and $\mathrm{O}_{2}$ into soil (Burke et al., 1999; McLain et al., 2002; McLain and Ahmann, 2007; West et al., 1999).

The R99 and C07 models incorporated parameters to address the limiting effects of low soil moisture levels on $\mathrm{CH}_{4}$ uptake fluxes. The R99 model applied a soil moisture factor adopted from Potter et al. (1986) where $r_{\mathrm{SM}}$ was calculated as a proportional ratio of precipitation $(P)$ plus soil moisture $(S M)$ divided by potential evapotranspiration (ET; Table 4, Eq. 21). It was assumed that $r_{\mathrm{SM}}$ decreases linearly when $(P+\mathrm{SM}) / \mathrm{ET}$ is less than 1 . The $\mathrm{C} 07$ model modified the response of soil methanotrophy to moisture using an empirical water stress parameterization and soil water potential based on findings from Clapp and Hornberger (1978) (Table 4, Eq. 22). A consequence of that approach is that $r_{\mathrm{SM}}$ decreases logarithmically to zero at an absolute soil water potential of $w<0.2 \mathrm{MPa}$ (Fig. 3).

In MeMo, soil moisture (\%) is used to calculate $r_{\mathrm{SM}}$ and a formulation similar to the $\mathrm{C} 07$ model is used for low soil moisture values. A threshold of $<20 \%$ soil moisture is applied because that value corresponds to optimum conditions for $\mathrm{CH}_{4}$ oxidation in soil (Castro et al., 1995; Whalen and Reeburgh, 1996) and because inclusion of a water stress parameter better captures $\mathrm{CH}_{4}$ uptake flux in dry ecosystems (Fig. 3; Curry, 2007).

Establishing parameters to quantify the impact of excess moisture on soil methanotrophy has proven more challenging. The $\mathrm{C} 07$ model relied upon soil pore space characteristics in factor $G_{\text {soil }}$ (Eq. 16) to account for decreased gas diffusion and limitation of $k_{d}$ at high soil moisture content. However, attenuation of gas diffusion is only one impact of high soil water content and it is necessary also to account for the inhibitory effects of excessive moisture on $k_{d}$ (Boeckx and Van Cleemput, 1996; van den Pol-van Dasselaar et al., 1998; 
Table 4. R99, C07 and MeMo model formulations for $r_{\mathrm{SM}}$ response.

\begin{tabular}{|c|c|c|c|}
\hline Model & Formulation & Eq. & Variable definitions \\
\hline R99 & $\begin{array}{l}r_{\mathrm{SM}}=1 \text { for } P+\mathrm{SM} / \mathrm{ET}_{\mathrm{p}}>1 \\
r_{\mathrm{SM}}=P+\mathrm{SM} / \mathrm{ET}_{\mathrm{p}} \text { for } \\
P+\mathrm{SM} / \mathrm{ET}_{\mathrm{p}} \leq 1\end{array}$ & (21) & $\begin{array}{l}P=\text { precipitation } \\
\mathrm{SM}=\text { soil moisture stored at } 30 \mathrm{~cm} \text { depth } \\
\mathrm{ET}_{\mathrm{p}}=\text { potential evapotranspiration }\end{array}$ \\
\hline C07 & $\begin{array}{l}r_{\mathrm{SM}}=1 \text { for } w<0.2 \mathrm{MPa} \\
r_{\mathrm{SM}}=\left[1-\frac{\log _{10} w-\log _{10}(0.2)}{\log _{10}(100)-\log _{10}(0.2)}\right]^{0.8} \text { for } w \geq 0.2 \leq 100 \mathrm{MPa}\end{array}$ & (22) & $w=$ saturation soil water potential \\
\hline MeMo & $\begin{array}{l}r_{\mathrm{SM}}=\left[1-\frac{\log _{10} \frac{1}{\mathrm{SM}-\log _{10}(0.2)}}{\log _{10}(100)-\log _{10}(0.2)}\right]^{0.8} \text { for } \mathrm{SM}<0.2 \\
r_{\mathrm{SM}}=\frac{1}{\sqrt[\sigma]{2 \pi}} e^{-\frac{1}{2}\left(\frac{\mathrm{SM}-0.2}{0.2}\right)^{2}} \text { for } \mathrm{SM}>0.2\end{array}$ & (23) & $\mathrm{SM}=$ soil moisture \\
\hline
\end{tabular}

Visvanathan et al., 1999). Soil moisture content $>20 \%$ reduces $\mathrm{CH}_{4}$ uptake due to a restricted diffusion of $\mathrm{CH}_{4}$ and supply of $\mathrm{O}_{2}$. The $\mathrm{R} 99$ and $\mathrm{C} 07$ models assume that microbial $\mathrm{CH}_{4}$ oxidation remains active at a soil moisture content of $80 \%$, an assumption that contradicts field investigations, which show that $\mathrm{CH}_{4}$ uptake decreases rapidly at soil moisture levels $>50 \%$ (van den Pol-van Dasselaar et al., 1998). Thus, the soil moisture factor employed in MeMo also accounts for limitation of microbial $\mathrm{CH}_{4}$ oxidation at a soil moisture content $>20 \%$ after which rates of $\mathrm{CH}_{4}$ uptake begin to decrease (Adamsen and King, 1993; Visvanathan et al., 1999). The $r_{\mathrm{SM}}$ factor used in MeMo was determined by fitting a Gaussian function to laboratory experimental data (Table 4, Eq. 23; Fig. 3a), following the approach of Del Grosso et al. (2000). The mean $r_{\mathrm{SM}}$ and standard deviation determined using this approach were $0.2 \pm 0.2$.

A soil moisture factor $\left(r_{\mathrm{SM}}\right)$ was calculated for each set of observational data from independent field sites (File 1 in the Supplement, Table S1) based upon an optimum rate of $\mathrm{CH}_{4}$ uptake occurring at a soil moisture content of $20 \%$ $\left(r_{\mathrm{SM}}=1\right)$. The remaining $r_{\mathrm{SM}}$ values were computed as a linear ratio of the $\mathrm{CH}_{4}$ uptake rate at $20 \%$ water content. Figure $3 \mathrm{~b}$ illustrates the pattern of response in methanotrophy rates to changes in soil moisture content in the R99, $\mathrm{C} 07$ models and MeMo, and the net effect on $\mathrm{CH}_{4}$ uptake fluxes across a range of absolute soil moisture levels used to force parameter $r_{\mathrm{SM}}$. The $\mathrm{CH}_{4}$ uptake fluxes were calculated by varying soil moisture content while holding constant all other environmental parameters (temperature, $\mathrm{C}_{\mathrm{CH}_{4}}$ and $N_{\text {dep }}$ ). The $\mathrm{R} 99$ and $\mathrm{C} 07$ models both predict greater $\mathrm{CH}_{4}$ uptake fluxes than MeMo at soil moisture contents $>20 \%$ with the R99 model yielding the highest flux rates; however, the $\mathrm{C} 07$ model and MeMo yield similar $\mathrm{CH}_{4}$ uptake rates for much of the soil moisture range. Reduction of $\mathrm{CH}_{4}$ uptake flux at high soil moisture levels due to attenuation of gas diffusion cannot be managed solely through the term $G_{\text {soil }}$ (i.e. reduction in free pore space). MeMo also accounts for inhibition of microbial $\mathrm{CH}_{4}$ oxidation rates at elevated soil moisture content, predicting lower $\mathrm{CH}_{4}$ uptake flux as a result of more realistic $r_{\mathrm{SM}}$ values determined from the Gaussian response observed in field data from three different global biomes (Luo et al., 2013).

\subsubsection{Temperature factor, $r_{\mathrm{T}}$}

Temperature exerts an important influence on rates of microbial processes, and consequently, all models parameterize for the effects of temperature on soil methanotrophy. The R99 model employs a $Q_{10}$ function derived from experimental data with a $Q_{10}$ factor of 2 change over the temperature interval 0 to $15^{\circ} \mathrm{C}$. The model assumes that bacterial methanotrophy ceases at temperatures $<0^{\circ} \mathrm{C}$ (Table 5, Eq. 24). The C07 model adopts the same $Q_{10}$ factor as R99 for temperatures $>0{ }^{\circ} \mathrm{C}$ but employs a different response below $0{ }^{\circ} \mathrm{C}$. Soil water generally does not freeze at a surface temperature of $0^{\circ} \mathrm{C}$, and observations from cold regions provide ample evidence for the presence of methanotrophic activity at temperatures $<0^{\circ} \mathrm{C}$ (Vecherskaya et al., 2013). The $\mathrm{C} 07$ model allows for a parabolic decrease of methanotrophy rates from 0 to $-10^{\circ} \mathrm{C}$ (Table 5, Eq. 25) based upon observations of $\mathrm{CH}_{4}$ uptake in soil at subzero temperatures (Del Grosso et al., 2000).

Parameterization of a temperature factor $\left(r_{\mathrm{T}}\right)$ is revisited in MeMo based upon availability of new experimental data for soil from different biomes (File 1 in the Supplement, Table S2). A $Q_{10}$ factor having a value of 1.95 was determined for the temperature interval 0 to $15^{\circ} \mathrm{C}$ by curve fitting and minimizing linear errors $\left(r^{2}=0.75, p=1.9 \times 10^{-11}\right.$; Table 5, Eq. 26). The factor $r_{\mathrm{T}}$ was determined by using the observed $\mathrm{CH}_{4}$ uptake flux at $10^{\circ} \mathrm{C}$ at each site as the base of the $Q_{10}$ function (Fig. 3c). An exponential decrease in $\mathrm{CH}_{4}$ uptake flux was assigned to the temperature range 0 to $-5^{\circ} \mathrm{C}$ as recommend by Castro et al. (1995) and Del Grosso et al. (2000). Moreover, the amount of frozen soil increases exponentially with decreasing temperatures (Low et al., 1968), and consequently, $\mathrm{CH}_{4}$ uptake also should decline exponentially. 
The pattern of change in the $r_{\mathrm{T}}$ factor and $\mathrm{CH}_{4}$ uptake flux for the temperature range -10 to $60^{\circ} \mathrm{C}$ is shown in Fig. 3d. The $\mathrm{CH}_{4}$ uptake fluxes shown were calculated by varying temperature while holding other environmental factors constant (i.e. soil moisture, $\mathrm{N}$ deposition or agricultural land use, and $C_{\mathrm{CH}_{4}}$ ). All models exhibit an optimum in $\mathrm{CH}_{4}$ uptake at $25^{\circ} \mathrm{C}$ characterized by a maximum $r_{\mathrm{T}}$ and $\mathrm{CH}_{4}$ oxidation rate. The key differences between models are the behaviour of $r_{\mathrm{T}}$ at temperatures below $0{ }^{\circ} \mathrm{C}$ and the amplitude of response curves. The R99 model assumes that methanotrophic activity ceases at $0{ }^{\circ} \mathrm{C}$, and consequently, $\mathrm{CH}_{4}$ uptake rates decrease sharply at that temperature. In contrast, the $\mathrm{C} 07$ and MeMo models both allow for methanotrophy at temperatures $<0{ }^{\circ} \mathrm{C}$. In general, the exponential decrease of $r_{\mathrm{T}}$ employed in MeMo more closely resembles natural patterns of soil methanotrophy at subzero temperatures than the parabolic decline employed in the $\mathrm{C} 07$ model consistent with observations reported by Castro et al. (1999) and Del Grosso et al. (2000). Although our parameterization yields a fit similar to $\mathrm{C} 07$ to the limited observations available at temperatures $<0{ }^{\circ} \mathrm{C}$, the $r_{\mathrm{T}}$ used in MeMo provides a simpler solution because it does not require multiple conditions to be met. In contrast, the $\mathrm{C} 07$ parameterization increases parabolically at temperatures $<-10^{\circ} \mathrm{C}$, which requires an additional condition to be incorporated into the model to prevent increased rates of $\mathrm{CH}_{4}$ uptake at very low temperatures. Soil $\mathrm{CH}_{4}$ uptake fluxes predicted by the $\mathrm{C} 07$ model are greater than those calculated using MeMo because of the different parameterization at temperatures $<0{ }^{\circ} \mathrm{C}$. Finally, the amplitude of the temperature response curve is greater and similar in the $\mathrm{C} 07$ and MeMo models compared to the R99 model, in particular, at temperatures $>25^{\circ} \mathrm{C}$ as a result of differences in the formulation and solution for $\mathrm{CH}_{4}$ uptake flux (Fig. 3d).

\subsubsection{Nitrogen deposition factor, $r_{\mathrm{N}}$}

The effect of nitrogen (N) deposition on $\mathrm{CH}_{4}$ uptake is not as well constrained as the effects of temperature and soil moisture. In general, field observations have shown that $\mathrm{CH}_{4}$ consumption rates, and thus uptake fluxes, decrease with $\mathrm{N}$ additions (Aronson and Helliker, 2010; Butterbach-Bahl and Papen, 2002; Steinkamp et al., 2001). Different processes have been suggested to explain this negative effect. Firstly, methanotrophs and ammonia oxidizers are capable of switching substrates (although the latter microorganisms typically consume $\mathrm{N}$ compounds preferentially if available), and therefore the presence of $\mathrm{N}$ compounds reduces $\mathrm{CH}_{4}$ consumption (Bradford et al., 2001; Gulledge and Schimel, 1998; Phillips et al., 2001; Wang and Ineson, 2003; Whalen, 2000). In addition, intermediate and end products from methanotrophic ammonia oxidation (i.e. hydroxylamine and nitrite) can be toxic to methanotrophic bacteria (Bronson and Mosier, 1994; MacDonald et al., 1996; Sitaula et al., 2000). Finally, large amounts of mineral fertilizers (i.e. ammonium salts) can induce osmotic stress in methanotrophs inhibiting $\mathrm{CH}_{4}$ con- sumption (Whalen, 2000). However, other studies suggest a positive effect of $\mathrm{N}$ fertilization on $\mathrm{CH}_{4}$ oxidation rates. One of the mechanisms invoked to explain the positive effect is a stimulation of nitrifying bacteria to consume $\mathrm{CH}_{4}$ by increased inputs of $\mathrm{N}$ due to an improvement in living conditions (Cai and Mosier, 2000; De Visscher and Cleemput, 2003; Rigler and Zechmeister-Boltenstern, 1999). The positive effect of $\mathrm{N}$ addition on $\mathrm{CH}_{4}$ oxidation rates has been observed primarily under experimental conditions and also greatly depends on the local microbial community structure. Therefore, we assumed that $\mathrm{N}$ has an inhibitory effect on uptake of atmospheric $\mathrm{CH}_{4}$ in all scenarios.

The C07 and R99 models both account for the negative effect of $\mathrm{N}$ inputs on $\mathrm{CH}_{4}$ uptake fluxes via the factor $r_{\mathrm{N}}$. In the R99 model, $r_{\mathrm{N}}$ directly affects $k_{d}$, while in the $\mathrm{C} 07$ model, $r_{\mathrm{N}}$ directly modifies the uptake flux. Both models parameterize the negative effect of $\mathrm{N}$ inputs on $\mathrm{CH}_{4}$ oxidation rates as a function of agricultural intensity (as a fraction of area) as a proxy for fertilizer application (Table 6, Eq. 27). However, the mathematical description of $r_{\mathrm{N}}$ used by the R99 and $\mathrm{C} 07$ models does not account for the enhanced $\mathrm{N}$ deposition by anthropogenic activity or direct $\mathrm{N}$ input via fertilizers because its global distribution was not well known at the time of model development. Here, we suggest a mathematical description of $r_{\mathrm{N}}$ that accounts for all anthropogenic $\mathrm{N}$ input sources: fossil fuel combustion, biomass burning and fertilizer application (Lamarque, 2013; Nishina et al., 2017).

The computation of $r_{\mathrm{N}}$ in MeMo is a function of (i) the inhibitory effect on $\mathrm{CH}_{4}$ uptake and (ii) the distribution and amount of $\mathrm{N}$ input in soil (Zhuang et al., 2013). We estimated the percent reduction of $\mathrm{CH}_{4}$ uptake per mole of $\mathrm{N}$ added based on field and laboratory observations (File 1 in the Supplement, Table S3). We determined an average inhibition $\alpha$ of $0.33 \% \mathrm{~mol} \mathrm{~N}^{-1}$ based on the mean uptake reduction per mole of $\mathrm{N}$ added. The $\mathrm{N}$ response function $r_{\mathrm{N}}$ was governed by Eq. (29):

$r_{\mathrm{N}}=1-\left(N_{\text {soil }} \times \alpha\right)$.

In the cases where entry of $\mathrm{N}$ into soil is limited by bulk density $\rho, 90 \%$ of $\mathrm{N}$ compounds tend to remain at depths $z<=5 \mathrm{~cm}$ before exponentially decreasing in concentration with depth (Schnell and King, 1994). Thus, $N_{\text {soil }}$ was calculated as $\mathrm{N}$ input $\left(\mathrm{kg} \mathrm{Nha}^{-1} \mathrm{yr}^{-1}\right)$ divided by $\rho$ at $z=5 \mathrm{~cm}$ :

$N_{\text {soil }}=\frac{N_{\text {dep }}+N_{\text {fert }}}{(\rho \times z)}$.

Figure 4 shows the change in $r_{\mathrm{N}}$ in relation to $\mathrm{N}$ input rate and the form of Eq. (29).

\section{Model implementation}

MeMo was implemented in $\mathrm{R}$ (version 3.0.1) and simulations were carried out with a spatial resolution of $1^{\circ} \times 1^{\circ}$ and a 
Table 5. R99, C07 and MeMo model formulations for $r_{\mathrm{T}}$ response.

\begin{tabular}{llll}
\hline Model & $T<0^{\circ} \mathrm{C}$ & $T \geq 0{ }^{\circ} \mathrm{C}$ & Eq. \\
\hline R99 & $r_{\mathrm{T}}=0$ & $r_{\mathrm{T}}=\exp \left(0.0693 T-8.56 \times 10^{-7} T^{4}\right)$ & $(24)$ \\
$\mathrm{C} 07$ & $r_{\mathrm{T}}=(0.1 T+1.0)^{2}$ if $T>-10^{\circ} \mathrm{C}$ & $r_{\mathrm{T}}=\exp \left(0.0693 T-8.56 \times 10^{-7} T^{4}\right)$ & $(25)$ \\
\hline MeMo & $r_{\mathrm{T}}=1 / \exp (-T)$ & $r_{\mathrm{T}}=\exp \left(0.1515+0.05238 T-5.946 \times 10^{-7} T^{4}\right)$ & $(26)$ \\
\hline
\end{tabular}

Table 6. R99, C07 and MeMo model formulations for $r_{\mathrm{N}}$ response.

\begin{tabular}{llll}
\hline Model & Formulation & Eq. & Driving data \\
\hline R99 & $r_{\mathrm{N}}=1.0-(0.75 \times I)$ & $(27)$ & $I=$ fractional intensity of cultivation \\
C07 & $r_{\mathrm{N}}=1.0-(0.75 \times I)$ & $(28)$ & $\begin{array}{l}I=\text { fractional intensity of cultivation } \\
\left(r_{\mathrm{N}} \text { outside of } \mathrm{k}_{d} \text { parameterization }\right)\end{array}$ \\
MeMo & $r_{\mathrm{N}}=1-\left(N_{\text {soil }}\right) \times \alpha$ & $(29)$ & $N_{\text {soil }}=\frac{N_{\text {dep }}+N_{\text {fert }}}{(\rho \times z)}$
\end{tabular}

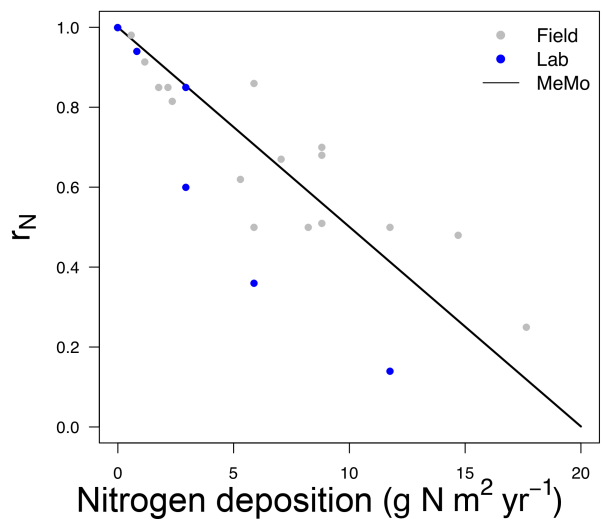

Figure 4. $\mathrm{CH}_{4}$ uptake response as a function of nitrogen deposition and fertilizer application factor $r_{\mathrm{N}}$. The linear fit (black line) is based on observations from field (long-term) and laboratory measurements (gray and blue dots; File 1 in the Supplement, Table S3).

monthly temporal resolution for the period between 1990 and 2009. The model code, a simple model case study for the year 2000 and output for 1990-2009 are available as the Supplement to this paper. To enable model-model comparisons and assess the combined effect of all refinements introduced in MeMo on the global $\mathrm{CH}_{4}$ uptake flux estimate, the $\mathrm{R} 99$ and $\mathrm{C} 07$ models also were implemented in $\mathrm{R}$ at identical spatial and temporal resolutions and forced using the same driving data.

\subsection{Forcing data}

MeMo and the C07 and R99 models were forced using global monthly observations of soil moisture, temperature, atmospheric $\mathrm{CH}_{4}$ concentration, $\mathrm{N}$ deposition, soil bulk density and clay content for the period 1990-2009. Information about data sources and maps of the forcing data are provided in File 3 in the Supplement.
Satellite observations of soil moisture at a spatial resolution of $1 \times 1^{\circ}$ and a monthly temporal resolution are available for the period 1990-2009 from Dorigo et al. (2011); however, the data set contains gaps in some regions (e.g. in areas of high-density vegetation). The use of MeMo as a predictive tool to estimate the past and future global $\mathrm{CH}_{4}$ soil sink relies strongly on the use of soil moisture from standard climate models, such as output from land surface models or dynamic global vegetation models (DGVMs). Therefore, gaps in the Dorigo et al. (2011) data set were filled using soil moisture data from an ensemble of nine DGVMs (TRENDY; Sitch et al., 2015). The R99 model parameterizes the effect of soil moisture on $\mathrm{CH}_{4}$ uptake fluxes as a function of precipitation and evaporation, and therefore R99 was forced using monthly data sets of precipitation (CRU3.1; Harris et al., 2014) and evapotranspiration (TRENDY; Sitch et al., 2015). Temperature forcing is constrained by global data sets for surface temperature as a proxy for soil temperature (CRU3.1; Harris et al., 2014). Monthly mean global atmospheric $\mathrm{CH}_{4}$ concentrations multiplied by the latitudinal atmospheric $\mathrm{CH}_{4}$ gradient were calculated from Rigby et al. (2008). The $\mathrm{N}$ deposition data were obtained from an atmospheric chemical transport model embedded in an Earth system model (Lamarque et al., 2013), and the $\mathrm{N}$ input via fertilizers was obtained from Nishina et al. (2017). Because the $\mathrm{R} 99$ and $\mathrm{C} 07$ models express the influence of $\mathrm{N}$ on $\mathrm{CH}_{4}$ uptake fluxes as a function of fraction agricultural area (see Sect. 2.3.6), R99 and C07 were forced using annual global gridded land-use change data from Hurtt et al. (2011). Finally, global gridded observations for bulk density and clay content were taken from Shangguan et al. (2014).

Areas that had less than $0.5 \%$ average annual soil moisture content were masked (e.g. Sahara) because it was assumed $\mathrm{CH}_{4}$ uptake is negligible under such conditions. If the areas were left unmasked, then MeMo would overestimate $\mathrm{CH}_{4}$ uptake across the regions due to high temporal 
variability in the driving data (e.g. a month with no moisture followed by a month with $>20 \%$ ). Irregular short-lived precipitation events in deserts led to unreliable estimates of soil uptake of atmospheric $\mathrm{CH}_{4}$ because such areas are unlikely to host well-established communities of methanotrophic bacteria capable of responding rapidly to short-term increases in soil moisture.

\section{Results and discussion}

The following sections critically evaluate MeMo estimates of the global $\mathrm{CH}_{4}$ sink (Sect. 4.1) as well as the regional distribution of $\mathrm{CH}_{4}$ uptake and its main drivers (Sect. 4.2) in the context of available field data and published model predictions.

\subsection{Global $\mathrm{CH}_{4}$ uptake by soils}

MeMo predicts an average annual global flux of $33.5 \pm 0.6 \mathrm{TgCH}_{4} \mathrm{yr}^{-1}$ for the period 1990 to 2009. Uncertainty in this flux was calculated as the standard deviation of annual global $\mathrm{CH}_{4}$ uptake. The estimated global uptake compares well with estimates from terrestrial ecosystem models, DGVMs and global atmospheric inversions (Table 7). Zhuang et al. (2013) determined a similar average global uptake flux of $34 \pm 2 \mathrm{TgCH}_{4} \mathrm{yr}^{-1}$ during the 21 st century using a process-based model included in the TEM while Spahni et al. (2011) estimated an uptake flux of $38.9 \mathrm{Tg} \mathrm{CH}_{4} \mathrm{yr}^{-1}$ using the LPJ-WHyMe DGVM. Hein et al. (1997) predicted a similar flux through atmospheric inversions but with a greater level of uncertainty $\left(30 \pm 15 \mathrm{Tg} \mathrm{CH}_{4} \mathrm{yr}^{-1}\right)$. Upscaling of field measurements of soil methanotrophy rates from 120 different studies spanning a wide range of ecosystems yielded an uptake flux of $36 \pm 23 \mathrm{TgCH}_{4} \mathrm{yr}^{-1}$ (Dutaur and Verchot, 2007). The large uncertainty associated with the mean flux results from differences in data representation for ecosystems and a tendency for sampling to be conducted seasonally rather than annually. In contrast, flux estimates based upon extrapolation of long-term records of $\mathrm{CH}_{4}$ uptake in a smaller number of soil types resulted in an estimated flux of $28.7 \mathrm{Tg} \mathrm{CH}_{4} \mathrm{yr}^{-1}$ (Dörr et al., 1993). Similarly, global extrapolation of measurements made solely on northern European soils yielded a sink strength of $29 \mathrm{Tg} \mathrm{CH}_{4} \mathrm{yr}^{-1}$ (Smith et al., 2000).

The average annual soil sink for atmospheric $\mathrm{CH}_{4}$ estimated by MeMo $\left(33.5 \pm 0.6 \mathrm{Tg} \mathrm{CH}_{4} \mathrm{yr}^{-1}\right)$ is greater than global uptake predicted using the P96 and C07 models ( $20 \pm 3$ and $29.3 \pm 0.6 \mathrm{Tg} \mathrm{CH}_{4} \mathrm{yr}^{-1}$, respectively). The $\mathrm{R} 99$ model predicts a global sink of $38.1 \pm 1.1 \mathrm{Tg} \mathrm{CH}_{4} \mathrm{yr}^{-1}$, which compares more favourably with the MeMo estimate. The observed differences in mean global soil uptake of atmospheric $\mathrm{CH}_{4}$ estimated using the R99, C07 and MeMo models forced with identical data are attributed primarily to
Table 7. Global $\mathrm{CH}_{4}$ uptake estimations.

\begin{tabular}{llr}
\hline Methodology & Reference & $\begin{array}{r}\text { Global } \\
\text { uptake by soils } \\
\left.\text { (Tg CH }_{4} \text { yr }^{-1}\right)\end{array}$ \\
\hline Observation & Dörr et al. (1993) & 28.7 \\
Observation & Smith et al. (2000) & 29 \\
Observation & Dutaur and Verchot (2007) & $36 \pm 23$ \\
Atmospheric & Hein et al. (1997) & $30 \pm 15$ \\
inversions & & $20 \pm 3$ \\
Model (P96) & Potter et al. (1996) & $38.1 \pm 1.1$ \\
Model (R99) & Ridgwell et al. (1999) & 38.9 \\
Model & Spahni et al. (2011) & $29.3 \pm 0.6$ \\
Model (C07) & Curry (2007) & $34 \pm 2$ \\
Model & Zhuang et al. (2013) & $33.5 \pm 0.6$ \\
Model (MeMo) & This study & \\
\hline
\end{tabular}

three factors: (i) their respective mathematical solutions of reaction-transport equations (Sect. 2.2), (ii) differences in parameterization of $k_{0}$ (Sect. 2.3.3) and (iii) differences in formulation of $r_{\mathrm{N}}$ (Sect. 2.3.6). The R99 model predicts soil uptake that is 12 and $24 \%$ greater, respectively, than fluxes estimated using MeMo and the $\mathrm{C} 07$ model. These differences are due to the R99 model applying a $k_{0}$ that is 1 order of magnitude greater than $k_{0}$ values used in the $\mathrm{C} 07$ model and MeMo. The amplifying effect of the large $k_{0}$ is partially offset by the semi-numerical approximation (Eq. 12) employed in the R99 model, which results in the final global $\mathrm{CH}_{4}$ uptake flux being of similar magnitude to the MeMo and the C07 model estimates. Finally, the low uptake predicted by the $\mathrm{C} 07$ model is a consequence of the parameterization of the nitrogen inhibition effect $\left(r_{\mathrm{N}}\right)$ and its direct modification of the $\mathrm{CH}_{4}$ flux rather than the $\mathrm{CH}_{4}$ oxidation activity $\left(k_{d}\right)$ (Sect. 2.3.3). Nitrogen inhibition was responsible for a global reduction in $\mathrm{CH}_{4}$ uptake of $1.4 \mathrm{Tg} \mathrm{yr}^{-1}$ in MeMo compared to 7.3 and $2.3 \mathrm{Tg} \mathrm{yr}^{-1}$ in the C07 and R99 models, respectively.

\subsection{Regional $\mathrm{CH}_{4}$ uptake by soils}

The latitudinal distribution of soil uptake rates of atmospheric $\mathrm{CH}_{4}$ predicted using the R99 and C07 models, and MeMo is shown in Fig. 5 accompanied by direct measurements of $\mathrm{CH}_{4}$ oxidation rates from Dutaur and Verchot (2007) and a $10^{\circ}$ running average. We chose to validate MeMo and previous models against regionally averaged observations to conduct the comparison at scales resolved by global models such as MeMo. This model is not intended to represent fine-scale site-specific attributes of soil but rather broad regional soil characteristics and $\mathrm{CH}_{4}$ uptake fluxes. 


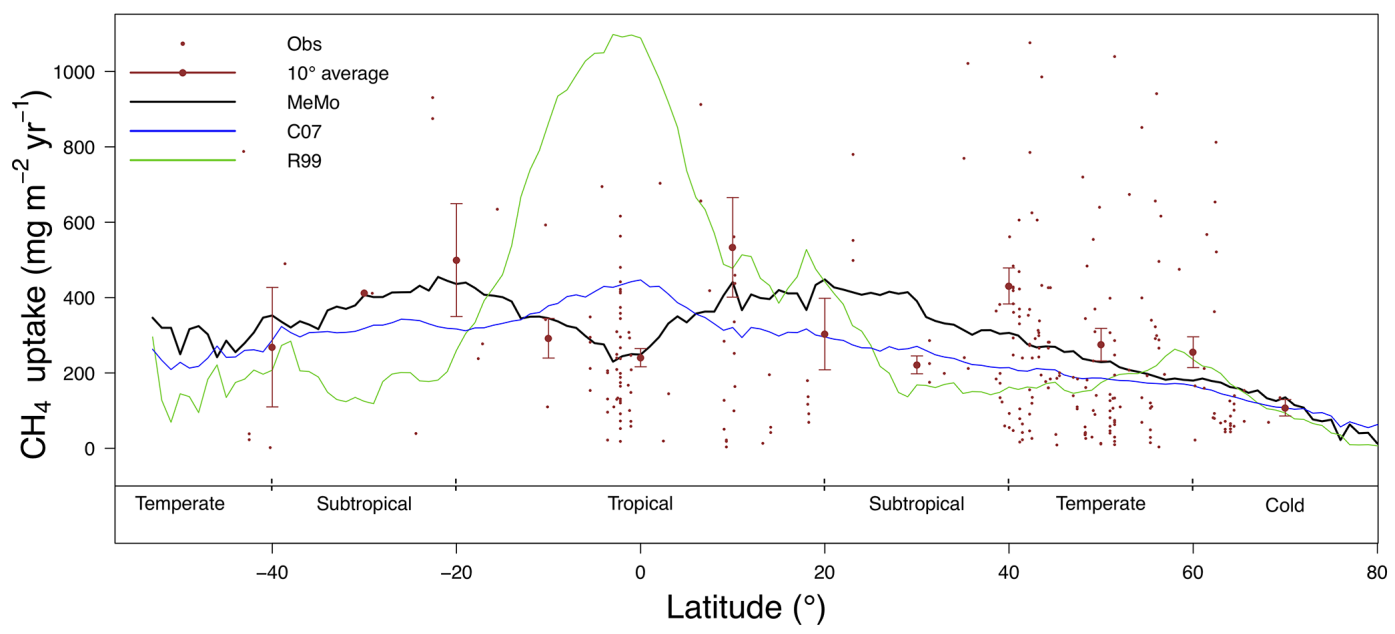

Figure 5. Latitudinal distribution of the soil uptake predicted by the R99 (green line), C07 (blue line) and MeMo (black line) models. Measurements of $\mathrm{CH}_{4}$ uptake (small brown dots; Dutaur and Verchot, 2007) and a $10^{\circ}$ running mean of direct observations (large brown dots for average with bars representing 1 standard deviation error).

The latitudinal distribution of observations reveals a scarcity of direct measurements of soil methanotrophy from sites in the Southern Hemisphere. Additionally, the frequency of measurements generally is low and rarely encompasses a full 12-month period, which creates challenges for verifying model estimates of annual $\mathrm{CH}_{4}$ uptake fluxes. $\mathrm{Ob}$ servations at specific latitudes typically exhibit a wide range of values, which are reflected in the large standard error bars calculated for the $10^{\circ}$ running means (Fig. 5). Nevertheless, the averages of direct observations calculated for each $10^{\circ}$ latitude interval show a distinct bimodal pattern with the lowest soil $\mathrm{CH}_{4}$ uptake fluxes in the tropics and at high latitudes. Maximum rates of $\mathrm{CH}_{4}$ uptake occur between 10 to $20^{\circ}$ latitude in both hemispheres (Fig. 5). MeMo simulates a similar bimodal latitudinal distribution of $\mathrm{CH}_{4}$ uptake fluxes with an RMSE that is $16.8 \mathrm{mg} \mathrm{CH}_{4} \mathrm{~m}^{-2} \mathrm{yr}^{-1}$ lower than other models when fitted to $10^{\circ}$ latitudinal averages of observational data. In contrast, the C07 and R99 models both predict a latitudinal distribution of soil methanotrophy that has $\mathrm{CH}_{4}$ uptake maxima in equatorial regions and lower rates of $\mathrm{CH}_{4}$ oxidation at midlatitudes $\left(\sim 40^{\circ} \mathrm{N}\right.$ and 20 to $\left.40^{\circ} \mathrm{S}\right)$, resulting in higher RMSEs of 28.6 and $72.1 \mathrm{mg} \mathrm{CH}_{4} \mathrm{~m}^{-2} \mathrm{yr}^{-1}$, respectively, when fitted to the $10^{\circ}$ latitude-averaged data. The R99 model significantly overestimates $\mathrm{CH}_{4}$ uptake fluxes in the tropics $\left(20^{\circ} \mathrm{N}\right.$ to $\left.20^{\circ} \mathrm{S}\right)$ and underestimates $\mathrm{CH}_{4}$ oxidation in the subtropics ( 20 to $40^{\circ} \mathrm{N}$ and S), resulting in large differences for these regions relative to the MeMo simulations (Fig. 6e). The $\mathrm{C} 07$ model predicts a latitudinal pattern of simulated $\mathrm{CH}_{4}$ fluxes that is similar to $\mathrm{R} 99$, however, with much lower uptake fluxes in the tropics and no pronounced minima in the subtropics. Consequently, the RMSE of the fit to observational data is much lower and regional differences relative to MeMo generally are smaller, ranging from $30 \%$ in the tropics to $20 \%$ in the subtropics (Fig. 6d).
The regional differences between MeMo and the R99 and $\mathrm{C} 07$ models result from differences in the parameterization of factors that govern $\mathrm{CH}_{4}$ oxidation rates in the models: $k_{0}$, $r_{\mathrm{SM}}, r_{\mathrm{T}}$ and $r_{\mathrm{N}}$. The lower $k_{0}$ assigned to tropical wet forest (see Sect. 2.3.3) accounts for the reduction in $\mathrm{CH}_{4}$ uptake by tropical soil in MeMo. The strong agreement between MeMo simulation results and $\mathrm{CH}_{4}$ uptake measurements presented in Fig. 5 suggests that the empirically derived lower $k_{0}$ value more accurately reflects soil $\mathrm{CH}_{4}$ oxidation rates in the tropics. However, we note the possibility that additional factors, or unexpected combinations of current factors, may influence rates of atmospheric $\mathrm{CH}_{4}$ uptake in the tropics in ways that are not explicitly represented in the models.

The influence of different environmental factors on soil $\mathrm{CH}_{4}$ uptake was assessed by calculating the global $\mathrm{CH}_{4}$ uptake flux while varying each factor (temperature, soil moisture and nitrogen input) independently and keeping other factors constant (Figs. 7-9). Comparison of $r_{\mathrm{SM}}$ values reveals large differences across models in tropical wet regions (Fig. 7), which explains the contrasting predictions of $\mathrm{CH}_{4}$ uptake by MeMo (213 $\mathrm{mg} \mathrm{CH}_{4} \mathrm{~m}^{-2} \mathrm{yr}^{-1}$ ) versus the $\mathrm{R} 99$ (689 $\mathrm{mg} \mathrm{CH}_{4} \mathrm{~m}^{-2} \mathrm{yr}^{-1}$ ) and $\mathrm{C} 07$ (329 $\mathrm{mg} \mathrm{CH}_{4} \mathrm{~m}^{-2} \mathrm{yr}^{-1}$ ) models. Formulation of $r_{\mathrm{SM}}$ in MeMo (Sect. 2.3.4) accounts for limitation of methanotrophic oxidation rates when soil moisture levels are at $>20 \%$ water content, a feature that is absent in the R99 and C07 models. In addition, the R99 model implements a linear decrease of $r_{\mathrm{SM}}$ for soil moisture conditions $<20 \%$, which results in a 60 to $80 \%$ reduction in $\mathrm{CH}_{4}$ oxidation rates in the subtopics. The absence of this condition in models MeMo and C07 explains the significant differences in $\mathrm{CH}_{4}$ uptake fluxes in subtropical regions (Figs. 5 and 6).

Formulations of $r_{\mathrm{T}}$ are similar in the three models (Sect. 2.3.5), and consequently, gridded maps of simulated $r_{\mathrm{T}}$ 

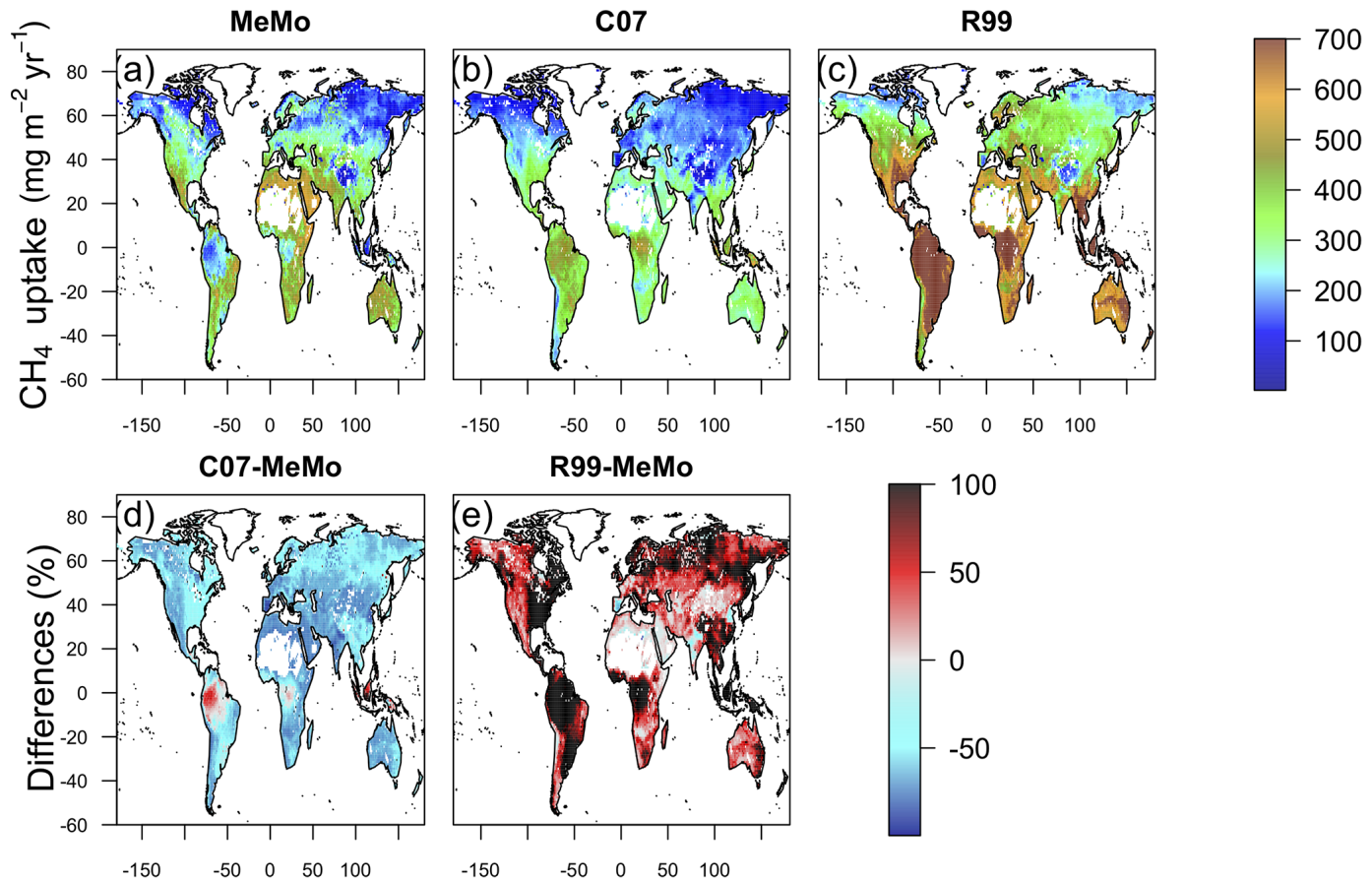

Figure 6. Annual mean $\mathrm{CH}_{4}$ uptake by soil predicted using models (a) MeMo, (b) C07 and (c) R99 for the period 1990-2009. Differences between models expressed in percent are shown in (d) C07 minus MeMo and (e) R99 minus MeMo.
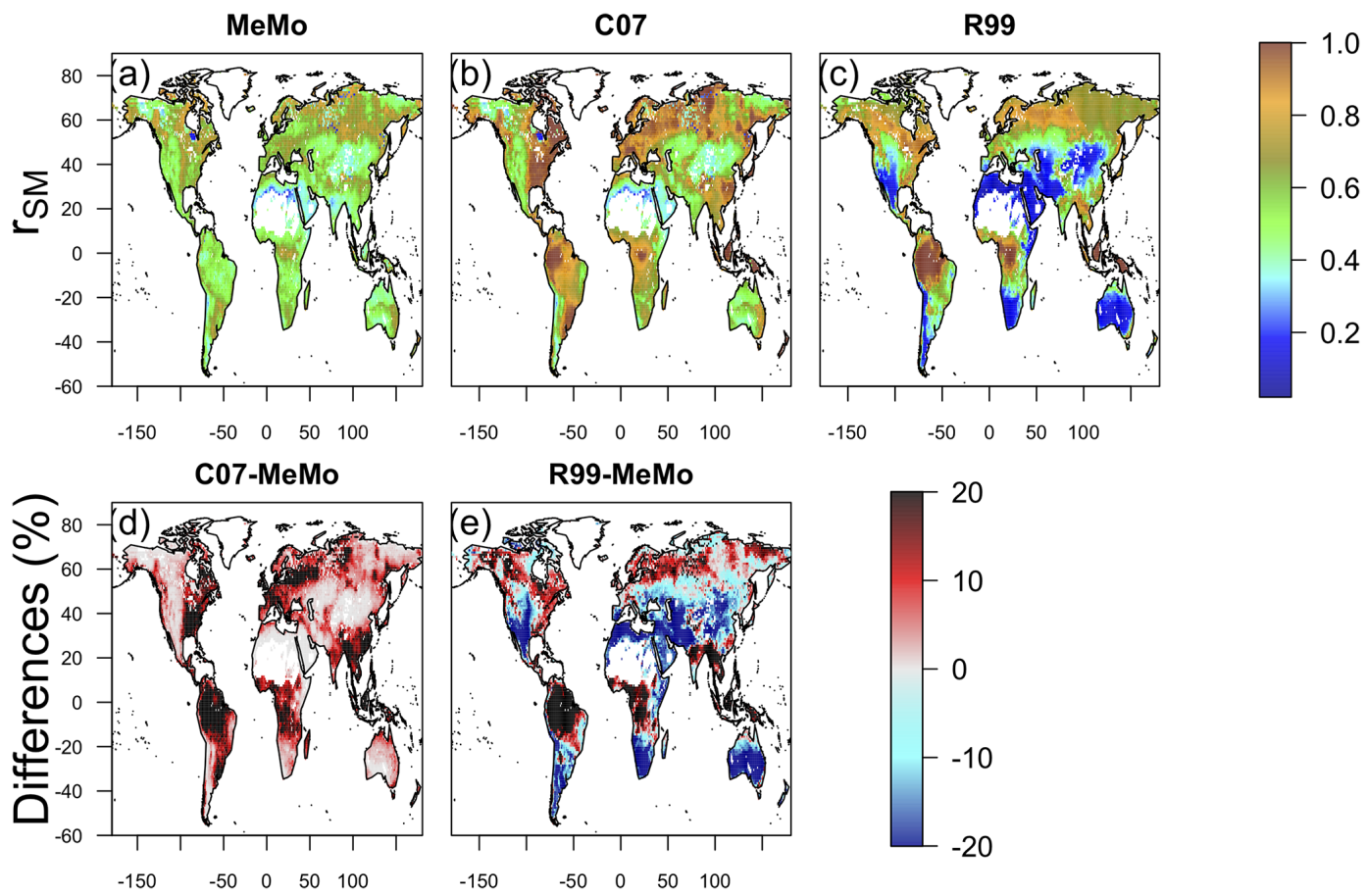

Figure 7. Soil moisture response $\left(r_{\mathrm{SM}}\right)$ of $\mathrm{CH}_{4}$ oxidation simulated by models (a) MeMo, (b) $\mathrm{C} 07$ and (c) R99. Differences in model response expressed in percent are shown in (d) C07 minus MeMo and (e) R99 minus MeMo.

values exhibit broadly similar global patterns in which high $r_{\mathrm{T}}$ values are present at warm low latitudes and low $r_{\mathrm{T}}$ values are predicted at cold high latitudes. Notably, MeMo gener- ally simulates $r_{\mathrm{T}}$ values that are approximately $20 \%$ lower than those predicted by the $\mathrm{C} 07$ and R99 models (Fig. 8) because of the revised formulation of the $Q_{10}$ value. MeMo and 
the C07 model simulate higher $r_{\mathrm{T}}$ values than R99 at high latitudes because of differences in parameterization of $r_{\mathrm{T}}$ at temperatures near $0{ }^{\circ} \mathrm{C}$.

Inhibition of soil methanotrophy due to $\mathrm{N}\left(r_{\mathrm{N}}\right)$ differs significantly between the three models. Nitrogen inhibition of $\mathrm{CH}_{4}$ oxidation rates is lower in MeMo compared to the $\mathrm{R} 99$ and C07 models, in particular, at midlatitudes (Fig. 9). The R99 and C07 models formulate $r_{\mathrm{N}}$ as a function of agricultural intensity in contrast to MeMo, which uses modelled $\mathrm{N}$ deposition and $\mathrm{N}$ input via fertilizers. The difference in approach results in an $r_{\mathrm{N}}$ factor that is up to $20 \%$ higher in MeMo across most regions with the exception of high latitude areas (Fig. 9).

In regions of intense agricultural activity and high $\mathrm{N}$ deposition $\left(\sim 150 \mathrm{~kg} \mathrm{Nha}^{-1}\right)$, such as Europe, the midwestern US, China and India, MeMo predicts a reduction in $\mathrm{CH}_{4}$ uptake rates of up to $60 \%$ on average, which is consistent with R99 and C07 models. However, inhibition of methanotrophy simulated by MeMo in areas experiencing low rates of $\mathrm{N}$ deposition is much smaller than R99 or C07. The key limitation of the $\mathrm{N}$ effect approach adopted in the R99 and C07 models is the generalization of $\mathrm{N}$ inhibitory effects across different agricultural areas, crops and types of land management, which results in a homogeneous and excessive attenuation of $\mathrm{CH}_{4}$ oxidation rates. In contrast, the MeMo $r_{\mathrm{N}}$ parameterization employs a more conservative $r_{\mathrm{N}}$ factor and a realistic regional distribution, which is based upon observational data that are consistent with recent studies reporting that high rates of $\mathrm{N}$ deposition $\left(10 \mathrm{~kg} \mathrm{Nha}^{-1} \mathrm{yr}^{-1}\right)$ can reduce soil uptake of atmospheric $\mathrm{CH}_{4}$ by $\sim 8.6 \%$ (Fang et al., 2014; Zhang et al., 2008). Direct application of fertilizers at more extreme rates $\left(>300 \mathrm{~kg} \mathrm{~N} \mathrm{ha}^{-1} \mathrm{yr}^{-1}\right.$ ) can entirely eliminate uptake of atmospheric $\mathrm{CH}_{4}$ by agricultural soil (Veldkamp et al., 2001). Nevertheless, the importance of accurate characterization of the attenuating effects of $\mathrm{N}$ addition on soil methanotrophy highlights the need for additional efforts to verify and refine parameterization of this key factor.

\subsection{Temporal and spatial variability of soil $\mathrm{CH}_{4}$ uptake}

Field observations of soil uptake of atmospheric $\mathrm{CH}_{4}$ are generally sparse both spatially and temporally. Consequently, our quantitative understanding of $\mathrm{CH}_{4}$ uptake fluxes across different ecosystems and seasons is limited. Models provide a means to quantitatively explore spatial and temporal patterns of soil methanotrophy on scales that cannot be readily captured by field-based observations. Therefore, once tested and validated (see Sect. 4.2), MeMo was used to quantitatively assess the variability of soil $\mathrm{CH}_{4}$ uptake in different climate zones and ecosystems on seasonal timescales.

\subsubsection{Regional variability}

The relative contribution of soil in each climatic zone to global uptake of atmospheric $\mathrm{CH}_{4}$ as predicted by MeMo is summarized in Table 8. Soil in the Northern Hemisphere is estimated to account for approximately two-thirds $(65 \%)$ of the total global sink for atmospheric $\mathrm{CH}_{4}$ because of the uneven distribution of landmasses between the Northern and Southern hemispheres. Notably, terrestrial areas in the northern subtropical and temperate zones collectively account for $\sim 45 \%$ of the global soil sink for atmospheric $\mathrm{CH}_{4}$. The southern tropical zone contributes a further $\sim 19 \%$ to soil uptake of $\mathrm{CH}_{4}$. The southern subtropical and northern tropical zones are estimated to contribute almost equally ( $\sim 14 \%)$ to total $\mathrm{CH}_{4}$ uptake (Table 8). The smallest proportion of soil $\mathrm{CH}_{4}$ oxidation occurs in the southern temperate $(0.6 \%)$ and northern polar $(5 \%)$ zones due to a combination of small land area and low rates of $\mathrm{CH}_{4}$ uptake. Model predictions of $\mathrm{CH}_{4}$ uptake by climatic zone provide insights into the relative importance of each region in the global $\mathrm{CH}_{4}$ cycle but additionally begin to facilitate analysis of potential responses of the soil $\mathrm{CH}_{4}$ sink within each zone to global change both due to climate and land management.

Further analysis of soil $\mathrm{CH}_{4}$ uptake by ecosystem types (Table 9) shows that the highest gridded mean rates of $\mathrm{CH}_{4}$ oxidation are associated with tropical deciduous forests $\left(602 \mathrm{mg} \mathrm{CH}_{4} \mathrm{~m}^{-2} \mathrm{yr}^{-1}\right)$. The relatively low soil moisture content during the dry season (File 2 in the Supplement, Fig. S3) and the consistently high mean annual temperature (File 2 in the Supplement, Fig. S7) in such ecosystems promote high rates of soil methanotrophy. Furthermore, the soil typically possesses a low clay content (File 2 in the Supplement, Fig. S2), which results in higher porosity that enhances gas diffusion and promotes higher rates of $\mathrm{CH}_{4}$ oxidation. In comparison, rates of $\mathrm{CH}_{4}$ uptake by soil in open and dense shrubland, temperate evergreen forest and savanna ecosystems (Table 9) are $\sim 100 \mathrm{mg} \mathrm{CH}_{4} \mathrm{~m}^{-2} \mathrm{yr}^{-1}$ lower but still highly significant globally.

Dense and open shrubland are characterized by constant climatic conditions (temperate and relatively low soil moisture; File 2 in the Supplement: Figs. S7 and S3, respectively) throughout the year, which, in combination with a soil texture that typically is sandy, results in high annual $\mathrm{CH}_{4}$ uptake rates (Tate et al., 2007). In contrast, high annual rates of $\mathrm{CH}_{4}$ uptake in temperate evergreen forests result from elevated rates of soil methanotrophy during summer months (Sect. 2.3.4), indicating that temperature is a key driver of $\mathrm{CH}_{4}$ oxidation in such ecosystems (Borken et al., 2006; Ueyama et al., 2015; Wang and Ineson, 2003). Savannas share many climatic conditions with tropical deciduous forests but also commonly experience wildfire during the dry season. Both ecosystem types though are characterized by a marked seasonality driven by the presence or absence of precipitation in combination with a consistent high mean annual temperature (File 2 in the Supplement, Figs. S7 and S3), which collectively support high rates of $\mathrm{CH}_{4}$ uptake by soil.

Tundra, taiga, polar desert and other ecosystem types that are common at high latitudes (File 2 in the Supplement, Fig. S10) are characterized by the lowest mean annual rates 

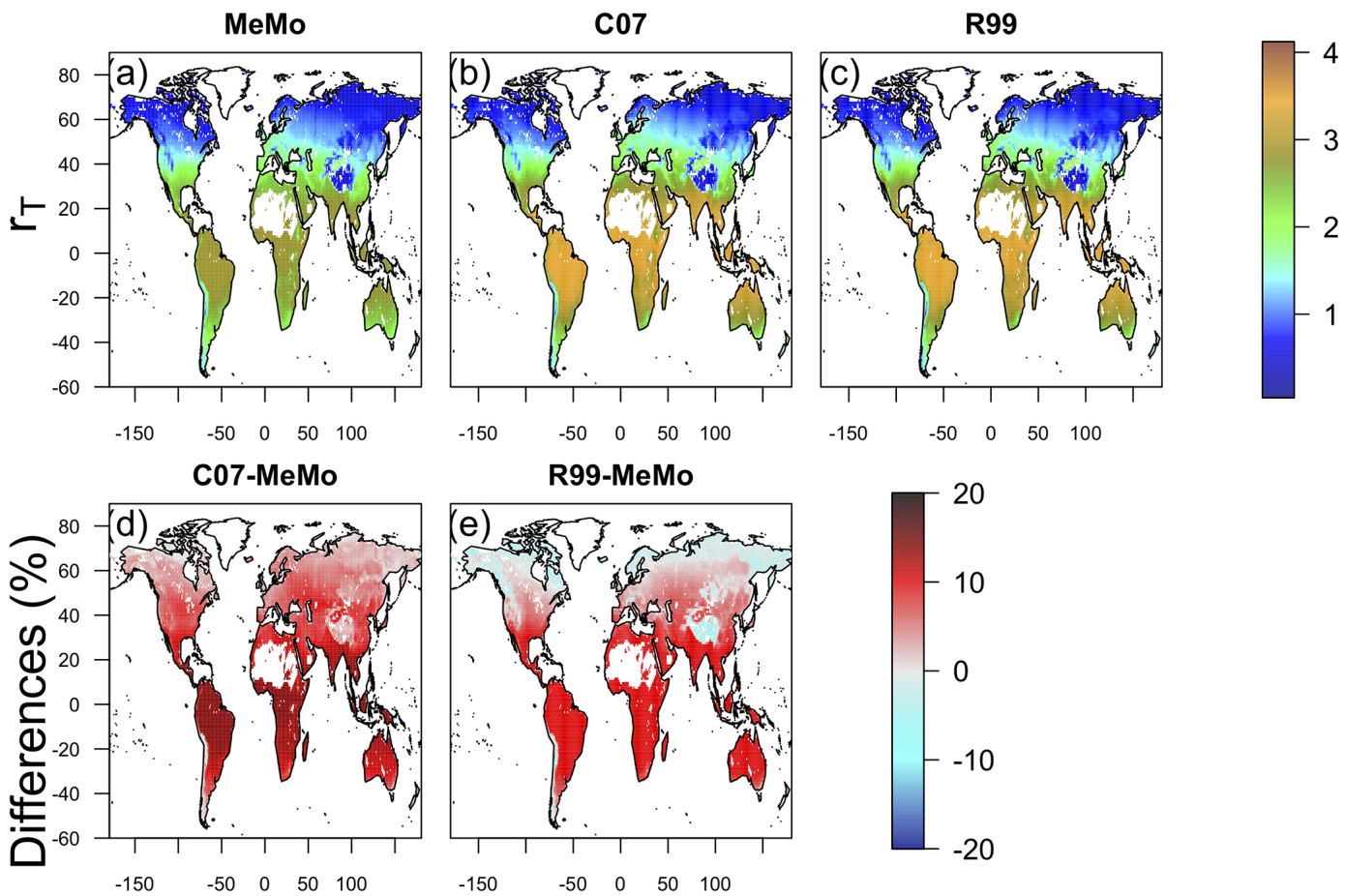

Figure 8. Temperature response $\left(r_{\mathrm{T}}\right)$ of soil methanotrophy simulated by models (a) MeMo, (b) C07 and (c) R99. Differences in model response expressed in percent are shown in (d) C07 minus MeMo and (e) R99 minus MeMo.
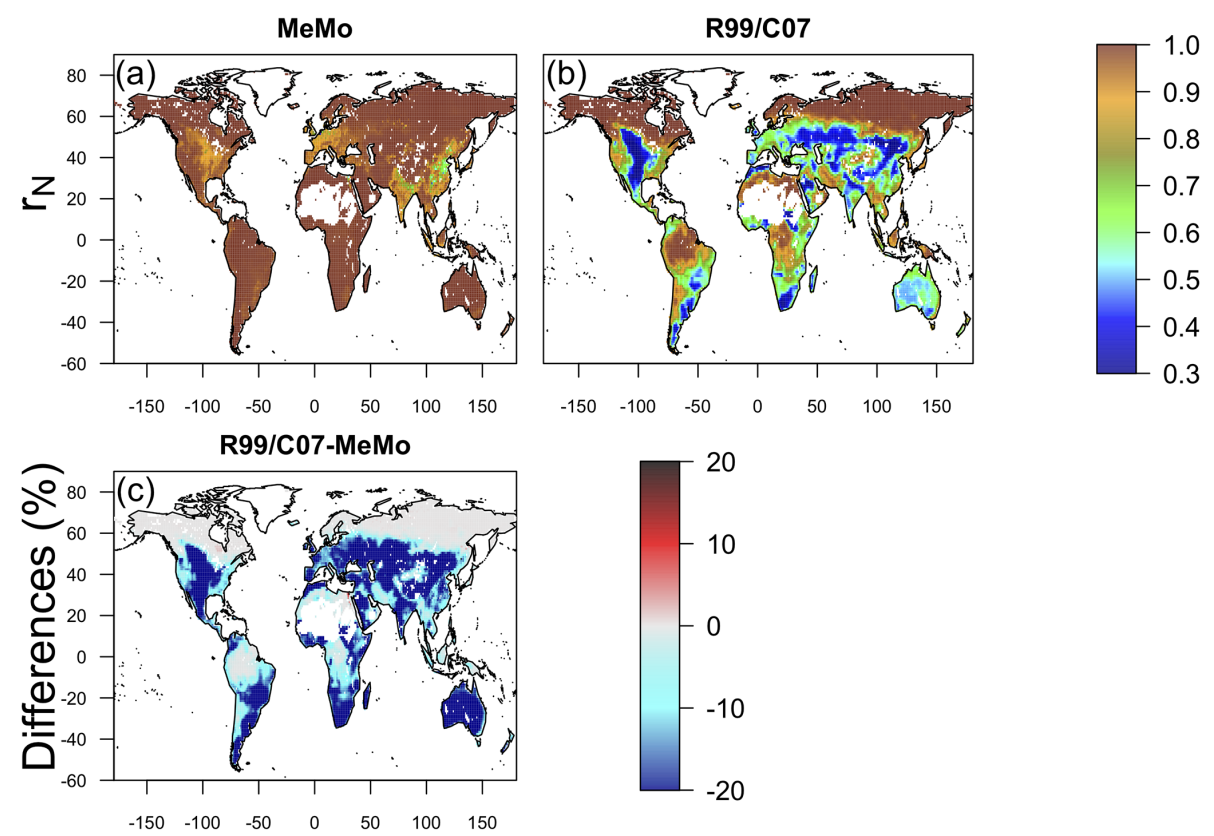

Figure 9. Response of soil methanotrophy to nitrogen effect $\left(r_{\mathrm{N}}\right)$ simulated by models (a) MeMo, (b) R99 and C07. The responses for the R99 and C07 models are both shown in panel (b) because they have the same formulation. The difference in model response between the R99/C07 models minus MeMo expressed in percent is shown in panel (c).

of soil methanotrophy ( $<180 \mathrm{mg} \mathrm{CH}_{4} \mathrm{~m}^{-2} \mathrm{yr}^{-1}$ ) because of low temperatures throughout most of the year. MeMo also predicts low rates of $\mathrm{CH}_{4}$ uptake in tropical humid forest
(332 $\mathrm{mg} \mathrm{CH}_{4} \mathrm{~m}^{-2} \mathrm{yr}^{-1}$ ) due to low rates of bacterial $\mathrm{CH}_{4}$ oxidation and the negative impact of high soil moisture levels on gas diffusion (see Sect. 2.3.5). The $\mathrm{CH}_{4}$ uptake rates 
Table 8. MeMo $\mathrm{CH}_{4}$ uptake estimates by region.

\begin{tabular}{lrrrr}
\hline Regions & $\begin{array}{r}\text { Regional gridded mean } \\
\left(\mathrm{mg} \mathrm{CH}_{4} \mathrm{~m}^{-2} \mathrm{yr}^{-1}\right)\end{array}$ & $\begin{array}{r}\text { Total land area } \\
\left(10^{12} \mathrm{~m}^{-2}\right)\end{array}$ & $\begin{array}{r}\text { Total } \mathrm{CH}_{4} \text { uptake } \\
\left(\mathrm{Tg} \mathrm{CH}_{4} \mathrm{yr}^{-1}\right)\end{array}$ & Percent of total \\
\hline Cold zone $\left(60-90^{\circ} \mathrm{N}\right)$ & 100.1 & 18.7 & 1.87 & 5.6 \\
Temperate zone $\left(40-60^{\circ} \mathrm{N}\right)$ & 217.0 & 31.0 & 6.7 & 20.0 \\
Subtropical zone $\left(20-40^{\circ} \mathrm{N}\right)$ & 326.6 & 26.4 & 8.6 & 25.7 \\
Tropical zone $\left(0-20^{\circ} \mathrm{N}\right)$ & 309.2 & 15.1 & 21.9 & 65.3 \\
\hline Total, Northern Hemisphere: & & 91.2 & 0.2 & 0.6 \\
\hline Temperate zone $\left(40-60^{\circ} \mathrm{S}\right)$ & 234 & 1.1 & 4.8 & 14.3 \\
Subtropical zone $\left(20-40^{\circ} \mathrm{S}\right)$ & 363.7 & 13.3 & 6.5 & 19.4 \\
Tropical zone $\left(0-20^{\circ} \mathrm{S}\right)$ & 313.9 & 20.8 & 11.6 & 34.6 \\
\hline Total, Southern Hemisphere: & & 35.2 & & \\
\hline
\end{tabular}

Table 9. MeMo $\mathrm{CH}_{4}$ uptake estimates by ecosystem type from Ramankutty and Foley (1999) land cover classification.

\begin{tabular}{|c|c|c|c|c|}
\hline Ecosystem type & $\begin{array}{l}\text { Global gridded mean } \\
\left(\mathrm{mg} \mathrm{CH}_{4} \mathrm{~m}^{-2} \mathrm{yr}^{-1}\right)\end{array}$ & $\begin{array}{l}\text { Total land area } \\
\left(\times 10^{12} \mathrm{~m}^{-2}\right)\end{array}$ & $\begin{array}{l}\text { Total } \mathrm{CH}_{4} \text { uptake } \\
\left(\mathrm{TgCH}_{4} \mathrm{yr}^{-1}\right)\end{array}$ & Percent of total \\
\hline Tropical deciduous forest & $602 \pm 63$ & 4.2 & 1.6 & 4.7 \\
\hline Open shrubland & $518 \pm 134$ & 23.3 & 6.6 & 19.7 \\
\hline Temperate broadleaf evergreen forest & $512 \pm 82$ & 2.0 & 0.6 & 1.7 \\
\hline Savanna & $500 \pm 132$ & 14.1 & 4.5 & 13.4 \\
\hline Dense shrubland & $481 \pm 90$ & 6.1 & 2.4 & 7.1 \\
\hline Grassland/steppe & $392 \pm 110$ & 15.8 & 5.0 & 15.0 \\
\hline Temperate needleleaf evergreen forest & $347 \pm 90$ & 3.9 & 1.2 & 3.5 \\
\hline Temperate deciduous forest & $321 \pm 70$ & 5.2 & 1.4 & 4.1 \\
\hline Tropical evergreen forest & $332 \pm 45$ & 12.5 & 2.5 & 7.4 \\
\hline Boreal deciduous forest & $282 \pm 117$ & 5.7 & 1.5 & 4.4 \\
\hline Boreal evergreen forest & $269 \pm 94$ & 9.1 & 2.4 & 7.1 \\
\hline Mixed forest & $182 \pm 82$ & 13.4 & 2.7 & 8.0 \\
\hline Tundra & $176 \pm 143$ & 6.2 & 1.1 & 3.2 \\
\hline Polar desert/rock/ice & $105 \pm 48$ & 0.4 & 0.01 & 0.0 \\
\hline Total & & 124.1 & 33.5 & 100 \\
\hline
\end{tabular}

estimated by MeMo are consistent with field observations by Dasselar et al. (1998) and Luo et al. (2013), which indicate that excess soil moisture strongly attenuates $\mathrm{CH}_{4}$ uptake rates across a range of ecosystem types.

Finally, the global significance of each ecosystem type as a $\mathrm{CH}_{4}$ sink depends strongly on spatial extent as well as $\mathrm{CH}_{4}$ oxidation rates. Open shrubland (19.7\%), grassland and steppe $(15.0 \%)$, and savanna $(13.4 \%)$ are the most important ecosystem types contributing to the global $\mathrm{CH}_{4}$ soil sink ( $\sim 8 \%$ collectively; Table 9$)$ in MeMo because of high mean rates of $\mathrm{CH}_{4}$ uptake ( 392 to $518 \mathrm{mg} \mathrm{CH}_{4} \mathrm{~m}^{-2} \mathrm{yr}^{-1}$ ) in combination with a large areal extent globally $\left(14 \times 10^{12}\right.$ to $23 \times 10^{12} \mathrm{~m}^{2}$ ). This finding is similar to the estimate reported by Potter et al. (1996) that warm and relatively dry ecosystems, such as semi-arid steppe, tropical savanna, tropical seasonal forest and chaparral, account for $40 \%$ of soil uptake of atmospheric $\mathrm{CH}_{4}$ globally. Moreover, Luo et al. (2013) reported the highest annual $\mathrm{CH}_{4}$ uptake rates in dry savanna as part of a long-term field investigation of soil methanotrophy in several ecosystem types. Singh et al. (1997) also observed $\mathrm{CH}_{4}$ uptake rates that were higher in savanna than in temperate forest. Although both model simulations and available field observations suggest these ecosystems are important global sinks for atmospheric $\mathrm{CH}_{4}$, there is presently a dearth of field measurements for warm and dry environments relative to temperate ecosystems.

\subsubsection{Seasonal variability}

Global annual uptake of atmospheric $\mathrm{CH}_{4}$ by soil exhibits a marked seasonality that reflects the dominance of the Northern Hemisphere in the soil sink. The highest simulated $\mathrm{CH}_{4}$ uptake fluxes occur during June, July and August (JJA) $\left(10.3 \mathrm{Tg} \mathrm{CH}_{4}\right)$ followed by September, October and November (SON) (10.1 $\mathrm{TgCH}_{4}$ ), March, April and May (MAM) 

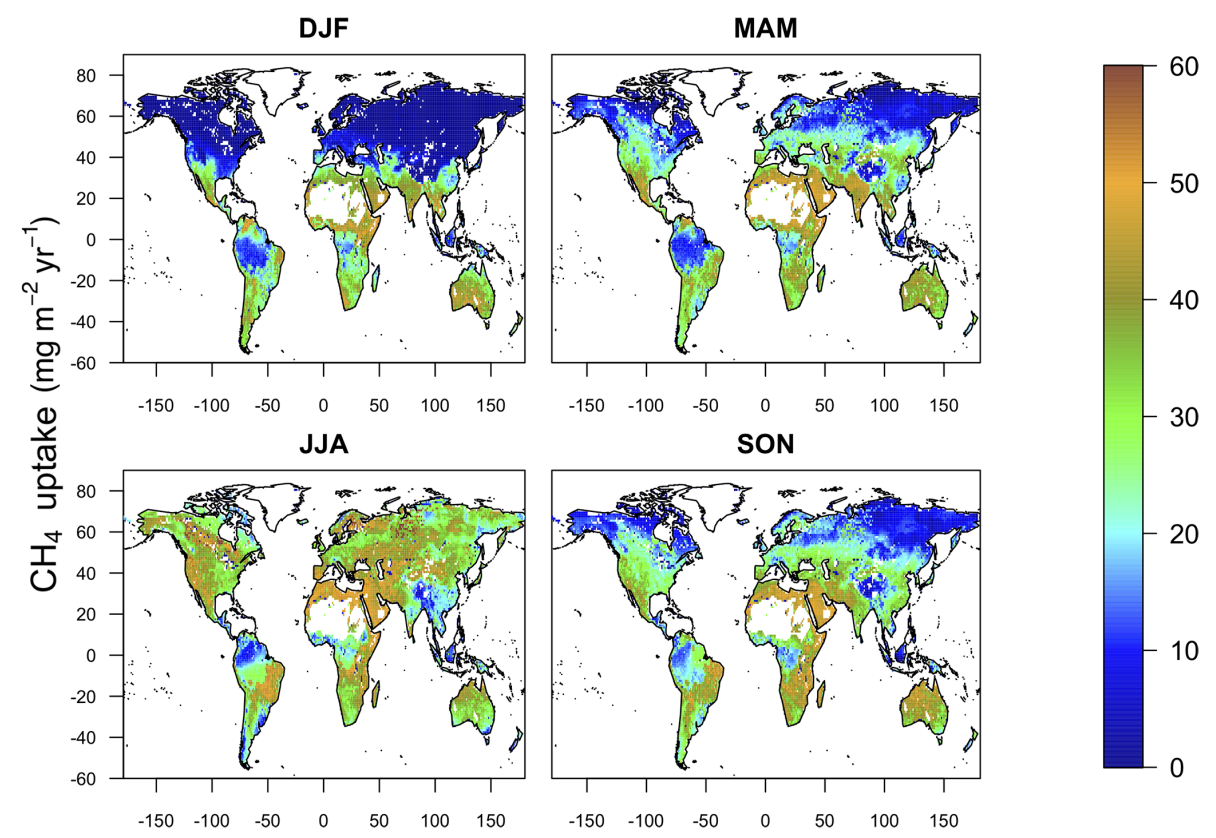

Figure 10. Seasonal uptake of atmospheric $\mathrm{CH}_{4}$ by global soils predicted by MeMo for the period 1990 to 2009 .

(6.8 $\left.\mathrm{Tg} \mathrm{CH}_{4}\right)$, and finally, December, January and February (DJF) (6.3 $\mathrm{Tg} \mathrm{CH}_{4}$ ) (Fig. 10).

Methane uptake in the cold and temperate regions of the Northern Hemisphere generally is characterized by the largest seasonality, exhibiting an amplitude of $30 \mathrm{mg} \mathrm{CH}_{4} \mathrm{~m}^{-2}$ month $^{-1}$. In these regions, modelled uptake of $\mathrm{CH}_{4}$ by soil is controlled strongly by temperature, and consequently, ecosystems common at these latitudes (e.g. boreal, needle leaf, temperate deciduous, mixed forest, polar deserts/rock/ice and tundra) show pronounced seasonal trends (Fig. 11), which also are evident in field measurements (e.g. Priemé and Christensen, 1997) and emphasized in local mechanistic models (e.g. Oh et al., 2016). These finding suggest that the soil $\mathrm{CH}_{4}$ sink in such ecosystems may be more sensitive to future change as a result of global warming.

In contrast, soil methanotrophy in temperate regions in the Southern Hemisphere is characterized by a weaker seasonality having an amplitude of $17 \mathrm{mg} \mathrm{CH}_{4} \mathrm{~m}^{-2}$ month $^{-1}$ due to the prevalence of grassland and steppe, which contrasts with a dominance of forest in the Northern Hemisphere. Seasonality of soil $\mathrm{CH}_{4}$ uptake fluxes is even more muted in tropical and subtropical environments $\left(<10 \mathrm{mg} \mathrm{CH}_{4} \mathrm{~m}^{-2}\right.$ month $\left.^{-1}\right)$ because of favourable and stable environmental conditions. Tropical deciduous forest and tropical evergreen forest, which are common in these climate zones, are characterized by relatively constant $\mathrm{CH}_{4}$ uptake fluxes throughout the year (Fig. 11); however, MeMo predicts greater seasonality ( $20 \mathrm{mg} \mathrm{CH}_{4} \mathrm{~m}^{-2}$ month $^{-1}$ ) of $\mathrm{CH}_{4}$ uptake by soil in drier subtropical ecosystems, such as open shrubland, savanna and grasslands (Fig. 11) because of seasonality in soil moisture.
Notably, northern temperate forest in summer (JJA) was the ecosystem and time period possessing the highest average monthly $\mathrm{CH}_{4}$ uptake fluxes $\left(76.7 \mathrm{mg} \mathrm{CH}_{4} \mathrm{~m}^{-2}\right.$ month $^{-1}$ ) simulated by MeMo. During the rest of the year, the largest soil sink for atmospheric $\mathrm{CH}_{4}$ occurred in the Southern Hemisphere in the tropical deciduous forest of central Africa (DJF, $69.5 \mathrm{mg} \mathrm{CH}_{4} \mathrm{~m}^{-2}$ month $^{-1}$; MAM, $\quad 73.5 \mathrm{mg} \mathrm{CH}_{4} \mathrm{~m}^{-2}$ month $^{-1}$; $\quad$ SON, $75.5 \mathrm{mg} \mathrm{CH}_{4} \mathrm{~m}^{-2} \mathrm{month}^{-1}$ ). This finding is significant because field observations of soil methanotrophy in northern temperate forest during summer are the measurements most commonly extrapolated to an annual basis, which may lead to a possible overestimation of global $\mathrm{CH}_{4}$ uptake fluxes.

\subsection{Model limitations and scope of applicability}

Several aspects of MeMo can be developed further, pending availability of new field data to improve estimation of global soil uptake of atmospheric $\mathrm{CH}_{4}$. Firstly, the base oxidation rate of bacterial methanotrophy at $0{ }^{\circ} \mathrm{C}\left(k_{0}\right)$ is a critical parameter necessary for accurate estimation of $\mathrm{CH}_{4}$ uptake rates. There is presently a general dearth of published $k_{0}$ values for soil methanotrophy, and moreover, ecosystem coverage is incomplete. Additionally, our parameterization for $k_{d}$ accounts for methanotrophic activity in a one-dimensional soil matrix; however, other studies have separated $\mathrm{CH}_{4}$ uptake in soil from methanotrophy in the rhizosphere to improve estimates of total $\mathrm{CH}_{4}$ uptake (e.g. Sabrekov et al., 2016). This refinement has been modelled for local conditions but insufficient data about rhizosphere $\mathrm{CH}_{4}$ oxidation rates prevent inclusion in MeMo and extension to a global scale. Secondly, the $Q_{10}$ response of soil methanotrophy has 

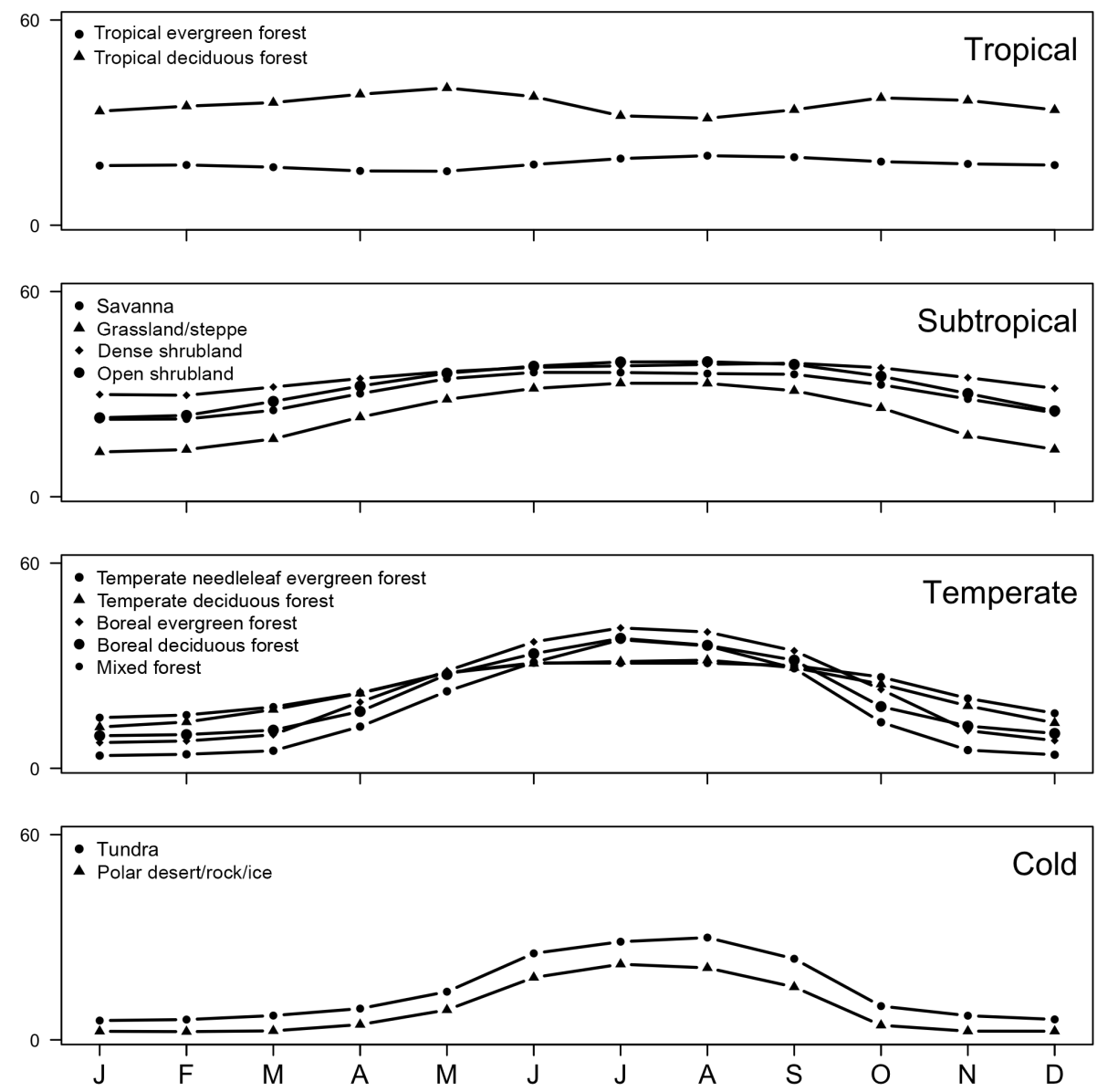

Figure 11. Seasonal patterns of soil uptake of atmospheric $\mathrm{CH}_{4}$ by ecosystem for the four regions: cold, temperate, tropical and subtropical using MeMo model for the period 1990-2009.

been determined to date in only a small subset of ecosystems in which soils function as a sink for atmospheric $\mathrm{CH}_{4}$. The majority of $Q_{10}$ values have been determined for bacterial oxidation of $\mathrm{CH}_{4}$ under laboratory conditions and there is considerable variability in values across different ecosystems. Thirdly, additional field observations of $\mathrm{CH}_{4}$ uptake by soil are needed, in particular, long-term measurements at individual sites that capture seasonality and interannual variability and from regions that presently have minimal or no representation (i.e. the Southern Hemisphere, semi-arid ecosystems) in the current pool of observations. Fourthly, additional observations and characterization of the effects of $\mathrm{N}$ deposition on soil methanotrophy are needed. The measurements ideally should be conducted in situ using $\mathrm{N}$ input rates that are appropriate for different environments and land-use practices. MeMo can be used to guide new field and laboratory experiments to address the lack of parameterization data, in particular, $k_{0}$ and $Q_{10}$ values for soil methanotrophy in different ecosystem and latitudes, and long-term in situ studies of $\mathrm{N}$ inhibition on $\mathrm{CH}_{4}$ uptake by soil. It also can be used to compare results from short- and long-term investigations of $\mathrm{CH}_{4}$ uptake in field and laboratory experiments.

MeMo is also parameterized to accommodate input of $\mathrm{CH}_{4}$ from below (i.e. subsurface methanogenesis or upward migration of deeply sourced $\mathrm{CH}_{4}$ ); however, rigorous validation of that aspect of the model will require additional field observations, including better characterization of conditions under which $\mathrm{CH}_{4}$ is produced in finely textured soils and deep sub-horizons. The presence, or periodic input, of high concentrations of $\mathrm{CH}_{4}$ (e.g. from permafrost melting) may impact competition for oxygen and niche space between lowaffinity $\mathrm{CH}_{4}$-oxidizing bacteria and the high-affinity methanotrophs responsible for uptake of atmospheric $\mathrm{CH}_{4}$. Refinement and validation of the capacity for MeMo to account for upward-migrating or autochthonous $\mathrm{CH}_{4}$ will enable the model to be used to estimate $\mathrm{CH}_{4}$ flux from intermittently wet environments, which may currently fall outside the scope of process-based wetland models.

The process-based nature of MeMo and the breadth of conditions for which it has been validated provide scope for using the model to quantify $\mathrm{CH}_{4}$ uptake in soil in a broad 
range of scenarios. For example, MeMo could be used to determine global uptake of $\mathrm{CH}_{4}$ by soil in the past during glacial or former interglacial periods. It may also be used to assess potential uptake rates of atmospheric $\mathrm{CH}_{4}$ in future climate scenarios and further elevated tropospheric $\mathrm{CH}_{4}$ mixing ratios. Additionally, MeMo can be used to evaluate the impact of different proposed policies and mitigation strategies for managing the atmospheric burden and growth rate of $\mathrm{CH}_{4}$ because of its capacity to evaluate different future scenarios based upon parameterization of key drivers that impact rates of $\mathrm{CH}_{4}$ uptake by soil globally.

\section{Conclusions}

We developed a processed-based model to simulate uptake of atmospheric $\mathrm{CH}_{4}$ by soil, which was refined using newly reported experimental data and the introduction of recent insights into physical and biological mechanisms that drive soil methanotrophy. We modified the general analytical solution proposed by Ridgwell et al. (1999) and Curry (2007) to account for a maximum depth of $\mathrm{CH}_{4}$ uptake and to quantify upward migration and consumption of $\mathrm{CH}_{4}$ produced in situ. Representation of the effects of $\mathrm{N}$ deposition and input via fertilizers, soil moisture and temperature on methanotrophy were improved based upon newly available data and recent advances in characterization of these processes. Finally, we proposed utilization of a different base oxidation rate $k_{0}$ for methanotrophy in different regions because its value changes in relation to environmental conditions.

MeMo simulations produced a closer fit to observational data than two previous soil methanotrophy models (Ridgwell et al., 1999; Curry, 2007). MeMo and observational data show a similar bimodal latitudinal distribution of atmospheric $\mathrm{CH}_{4}$ uptake by soil with the lowest fluxes at the Equator and high latitudes, and largest uptake fluxes at midlatitudes. Previous models simulated a dissimilar pattern with large uptake fluxes in equatorial regions, a difference that results primarily from improved representation of the soil moisture effect in MeMo.

MeMo simulations supported by observational data indicate that warm and semi-arid regions are the most efficient soil sink for atmospheric $\mathrm{CH}_{4}$. In these regions, tropical deciduous forest and dense open shrubland are characterized by relatively low soil moisture and constant temperature during the year, which are key factors that promote high rates of $\mathrm{CH}_{4}$ uptake by soil. In contrast, cold regions possessed the lowest $\mathrm{CH}_{4}$ uptake rates, in particular, tundra and boreal forest, which have a marked seasonality driven by temperature, making soil methanotrophy in such areas potentially sensitive to future global climate change. The warm and wet tropical evergreen forest biome has $\mathrm{CH}_{4}$ uptake rates that are $\sim 50 \%$ less than warm and semi-arid regions because excess soil moisture impacts soil-atmosphere gas exchange, resulting in a smaller $k_{0}\left(1.6 \times 10^{-5} \mathrm{~s}^{-1}\right)$. The extensive area of shrubland, grassland, steppe and savanna globally yields a high total uptake of $\mathrm{CH}_{4}$; however, there is presently a dearth of experimental data for these biomes and additional field observations are required to strengthen validation of MeMo simulations for these globally extensive areas.

MeMo simulations indicate that global soil uptake of atmospheric $\mathrm{CH}_{4}$ is reduced $4 \%$ on average and by as much as $60 \%$ in regions that receive high rates of atmospheric $\mathrm{N}$ deposition and $\mathrm{N}$ input from fertilizers. Globally, $\mathrm{N}$ deposition and input via fertilizers attenuates the soil sink for atmospheric $\mathrm{CH}_{4}$ by $1.38 \mathrm{Tg} \mathrm{yr}^{-1}$, which is $2-5$ times less than previously reported values because of the refined representation of the nitrogen inhibition on soil $\mathrm{CH}_{4}$ oxidation in MeMo.

The accuracy of quantifying the modern soil sink for atmospheric $\mathrm{CH}_{4}$ is improved using MeMo. In addition, the model can be used to explore changes in the relative importance of soil methanotrophy in the global $\mathrm{CH}_{4}$ cycle in the past and the capacity of the soil sink to consume atmospheric $\mathrm{CH}_{4}$ under future global change scenarios.

Code and data availability. MeMo was implemented in R (version 3.0.1). The model code and model output for 1990-2009 are available as the Supplement to this paper. In addition, we also provide a postprocessed driving data set to run an example model case study for the year 2000. All forcing data used in this study are available from the following sources:

- temperature from CRU3.1, Harris et al. (2014): https://crudata.uea.ac.uk/cru/data/hrg/;

- vegetation mask from Ramankutty and Foley (1999): https://nelson.wisc.edu/sage/data-and-models/ global-potential-vegetation/index.php;

- soil moisture from Dorigo et al. (2011) (satellite): http://www.esa-soilmoisture-cci.org;

- soil moisture from TRENDY: (Sitch et al., 2015): http://www-lscedods.cea.fr/invsat/RECCAP/;

- nitrogen deposition from Lamarque et al. (2013):

a. https://www.isimip.org/gettingstarted/ downloading-input-data/

b. https://www.isimip.org/gettingstarted/details/24/;

- N input via fertilizers from Nischina et al. (2017): https://www.earth-syst-sci-data.net/9/149/2017/;

- clay content and bulk density from Shangguan et al. (2014): http://globalchange.bnu.edu.cn.

Supplement. The supplement related to this article is available online at: https://doi.org/10.5194/gmd-11-2009-2018-supplement. 
Author contributions. FMF and SA developed and modified the model. FMF and GMT created the code. FMF ran the simulations, analysed the data and created all figures. All authors contributed to the interpretation of the results and preparation of the paper.

Competing interests. The authors declare that they have no conflict of interest.

Acknowledgements. CONACyT Mexico is thanked for providing $\mathrm{PhD}$ funding support to Fabiola Murguia-Flores. Sandra Arndt acknowledges funding from the European Union's Horizon 2020 research and innovation programme under the Marie SklodowskaCurie grant agreement no. 643052745 (C-CASCADES project). Anita L. Ganesan is funded by a UK Natural Environment Research Council Independent Research Fellowship NE/L010992/1. Guillermo Murray-Tortarolo thanks the Universidad Nacional Autonoma de Mexico for providing funding during his postdoctoral studies and CONACyT for funding during the "Catedra CONACyT". We thank Guangjuan Luo and Klaus Butterbach-Bahl for providing methane uptake data from their long-term observational sites. The TRENDY modelling compendium is gratefully acknowledged for providing soil moisture data.

Edited by: Tomomichi Kato

Reviewed by: three anonymous referees

\section{References}

Adamsen, A. P. S. and King, G. M.: Methane Consumption in Temperate and Subarctic Forest Soils: Rates, Vertical Zonation, and Responses to Water and Nitrogen, Appl. Environ, Microbiol., 59, 485-490, 1993.

Allan, W., Struthers, H., and Lowe, D. C.: Methane carbon isotope effects caused by atomic chlorine in the marine boundary layer: Global model results compared with Southern Hemisphere measurements, J. Geophys. Res.-Atmos., 112, D04306, https://doi.org/10.1029/2006JD007369, 2007.

Arndt, S., Jørgensen, B. B., LaRowe, D. E., Middelburg, J. J., Pancost, R. D., and Regnier, P.: Quantifying the degradation of organic matter in marine sediments: A review and synthesis, Earth-Sci. Rev., 123, 53-86, https://doi.org/10.1016/j.earscirev.2013.02.008, 2013.

Aronson, E. L. and Helliker, B. R.: Methane flux in non-wetland soils in response to nitrogen addition: a meta-analysis, Ecology, 91, 3242-3251, https://doi.org/10.1890/09-2185.1, 2010.

Bodelier, P. L. E. and Laanbroek, H. J.: Nitrogen as a regulatory factor of methane oxidation in soils and sediments, FEMS Microbiol. Ecol., 47, 265-277, https://doi.org/10.1016/S01686496(03)00304-0, 2004.

Boeckx, P. and Van Cleemput, O.: Methane Oxidation in a Neutral Landfill Cover Soil: Influence of Moisture Content, Temperature, and Nitrogen-Turnover, J. Environ. Qual., 25, 178, https://doi.org/10.2134/jeq1996.00472425002500010023x, 1996.

Borken, W., Davidson, E. A., Savage, K., Sundquist, E. T., and Steudler, P.: Effect of summer throughfall exclusion, sum- mer drought, and winter snow cover on methane fluxes in a temperate forest soil, Soil Biol. Biochem., 38, 1388-1395, https://doi.org/10.1016/j.soilbio.2005.10.011, 2006.

Born, M., Dörr, H., and Levin, I.: Methane consumption in aerated soils of the temperate zone, Tellus B, 42, 2-8, https://doi.org/10.1034/j.1600-0889.1990.00002.x, 1990.

Bradford, M. A., Ineson, P., Wookey, P. A., and Lappin-Scott, H. M.: The effects of acid nitrogen and acid sulphur deposition on $\mathrm{CH}_{4}$ oxidation in a forest soil: a laboratory study, Soil Biol. Biochem., 33, 1695-1702, https://doi.org/10.1016/S0038-0717(01)000918, 2001.

Bradley, J. A., Anesio, A. M., and Arndt, S.: Bridging the divide: a model-data approach to Polar and Alpine microbiology, FEMS Microbiol. Ecol., 92, fiw015, https://doi.org/10.1093/femsec/fiw015, 2016.

Brady, N. C., Weil, R. R., and Weil, R.: The Nature and Properties of Soils, Prentice-Hall, Upper Sadler River, 881 pp., 1999.

Bronson, K. F. and Mosier, A. R.: Suppression of methane oxidation in aerobic soil by nitrogen fertilizers, nitrification inhibitors, and urease inhibitors, Biol. Fertil. Soils, 17, 263-268, https://doi.org/10.1007/BF00383979, 1994.

Burke, R. A., Meyer, J. L., Cruse, J. M., Birkhead, K. M., and Paul, M. J.: Soil-atmosphere exchange of methane in adjacent cultivated and floodplain forest soils, J. Geophys. Res.-Atmos., 104, 8161-8171, https://doi.org/10.1029/1999JD900015, 1999.

Butterbach-Bahl, K. and Papen, H.: Four years continuous record of $\mathrm{CH}_{4}$-exchange between the atmosphere and untreated and limed soil of a N-saturated spruce and beech forest ecosystem in Germany, Plant Soil, 240, 77-90, https://doi.org/10.1023/A:1015856617553, 2002.

Cai, Z. C. and Mosier, A. R.: Effect of $\mathrm{NH}_{4} \mathrm{Cl}$ addition on methane oxidation by paddy soils, Soil Biol. Biochem., 32, 1537-1545, https://doi.org/10.1016/S0038-0717(00)00065-1, 2000.

Castro, M. S., Steudler, P. A., Melillo, J. M., Aber, J. D., and Bowden, R. D.: Factors controlling atmospheric methane consumption by temperate forest soils, Global Biogeochem. Cy., 9, 1-10, https://doi.org/10.1029/94GB02651, 1995.

Ciais, P., Sabine, C., Bala, G., Bopp, L., Brovkin, V., Canadell, J., Chhabra, A., DeFries, R., Galloway, J., Heimann, M., Jones, C., Le Quéré, C., Myneni, R. B., Piao, S., and Thornton, P.: Carbon and Other Biogeochemical Cycles, in: Climate Change 2013: The Physical Science Basis. Contribution of Working Group I to the Fifth Assessment Report of the Intergovernmental Panel on Climate Change, edited by: Stocker, T. F., Qin, D., Plattner, G.K., Tignor, M., Allen, S. K., Boschung, J., Nauels, A., Xia, Y., Bex, V., and Midgley, P. M., Cambridge University Press, Cambridge, UK, New York, NY, USA, 2013.

Clapp, R. B. and Hornberger, G. M.: Empirical equations for some soil hydraulic properties, Water Resour. Res., 14, 601-604, https://doi.org/10.1029/WR014i004p00601, 1978.

Curry, C. L.: Modeling the soil consumption of atmospheric methane at the global scale, Global Biogeochem. Cy., 21, GB4012, https://doi.org/10.1029/2006GB002818, 2007.

Czepiel, P. M., Crill, P. M., and Harriss, R. C.: Environmental factors influencing the variability of methane oxidation in temperate zone soils, J. Geophys. Res.-Atmos., 100, 9359-9364, https://doi.org/10.1029/95JD00542, 1995.

Del Grosso, S. J., Parton, W. J., Mosier, A. R., Ojima, D. S., Potter, C. S., Borken, W., Brumme, R., Butterbach-Bahl, K., 
Crill, P. M., Dobbie, K., and Smith, K. A.: General $\mathrm{CH}_{4}$ oxidation model and comparisons of $\mathrm{CH}_{4}$ Oxidation in natural and managed systems, Global Biogeochem. Cy., 14, 999-1019, https://doi.org/10.1029/1999GB001226, 2000.

De Visscher, A. and Cleemput, O. V.: Induction of enhanced $\mathrm{CH}_{4}$ oxidation in soils: $\mathrm{NH}_{4}^{+}$inhibition patterns, Soil Biol. Biochem., 35, 907-913, https://doi.org/10.1016/S0038-0717(03)00122-6, 2003.

Dorigo, W. A., Wagner, W., Hohensinn, R., Hahn, S., Paulik, C., Xaver, A., Gruber, A., Drusch, M., Mecklenburg, S., van Oevelen, P., Robock, A., and Jackson, T.: The International Soil Moisture Network: a data hosting facility for global in situ soil moisture measurements, Hydrol. Earth Syst. Sci., 15, 1675-1698, https://doi.org/10.5194/hess-15-1675-2011, 2011.

Dörr, H., Katruff, L., and Levin, I.: Proceedings of the NATO advanced research workshop Soil texture parameterization of the methane uptake in aerated soils, Chemosphere, 26, 697-713, https://doi.org/10.1016/0045-6535(93)90454-D, 1993.

Dutaur, L. and Verchot, L. V.: A global inventory of the soil $\mathrm{CH}_{4}$ sink, Global Biogeochem. Cy., 21, GB4013, https://doi.org/10.1029/2006GB002734, 2007.

Epstein, H. E., Burke, I. C., Mosier, A. R., Hutchinson, G. L.: Plant functional type effects on trace gas fluxes in the shortgrass steppe, in: Plant-Induced Soil Changes: Processes and Feedbacks, Developments in Biogeochemistry, edited by: Breemen, N. V., Springer Netherlands, 145-168, 1998.

Etheridge, D. M., Steele, L. P., Francey, R. J., and Langenfelds, R. L.: Atmospheric methane between 1000 A.D. and present: Evidence of anthropogenic emissions and climatic variability, J. Geophys. Res.-Atmos., 103, 15979-15993, https://doi.org/10.1029/98JD00923, 1998.

Fang, H., Cheng, S., Yu, G., Cooch, J., Wang, Y., Xu, M., Li, L., Dang, X., and Li, Y.: Low-level nitrogen deposition significantly inhibits methane uptake from an alpine meadow soil on the Qinghai-Tibetan Plateau, Geoderma, 213, 444-452, https://doi.org/10.1016/j.geoderma.2013.08.006, 2014.

Gulledge, J. and Schimel, J. P.: Low-Concentration Kinetics of Atmospheric $\mathrm{CH}_{4}$ Oxidation in Soil and Mechanism of $\mathrm{NH}_{4}^{+}$Inhibition, Appl. Environ. Microbiol., 64, 4291-4298, 1998.

Harris, I., Jones, P. D., Osborn, T. J., and Lister, D. H.: Updated high-resolution grids of monthly climatic observations - the CRU TS3.10 Dataset, Int., J. Climatol., 34, 623-642, https://doi.org/10.1002/joc.3711, 2014.

Hein, R., Crutzen, P. J., and Heimann, M.: An inverse modelling approach to investigate the global atmospheric methane cycle, Global Biogeochem. Cy., 11, 43-76, https://doi.org/10.1029/96GB03043, 1997.

Ho, A., Kerckhof, F.-M., Luke, C., Reim, A., Krause, S., Boon, N., and Bodelier, P. L. E.: Conceptualizing functional traits and ecological characteristics of methane-oxidizing bacteria as life strategies, Environ. Microbiol. Rep., 5, 335-345, https://doi.org/10.1111/j.1758-2229.2012.00370.x, 2013.

Hurtt, G. C., Chini, L. P., Frolking, S., Betts, R. A., Feddema, J., Fischer, G., Fisk, J. P., Hibbard, K., Houghton, R. A., Janetos, A., Jones, C. D., Kindermann, G., Kinoshita, T., Goldewijk, K. K., Riahi, K., Shevliakova, E., Smith, S., Stehfest, E., Thomson, A., Thornton, P., Vuuren, D. P., and van Wang, Y. P.: Harmonization of land-use scenarios for the period 1500-2100: 600 years of global gridded annual land-use transitions, wood har- vest, and resulting secondary lands, Clim. Change, 109, 117161, https://doi.org/10.1007/s10584-011-0153-2, 2011.

Kirschke, S., Bousquet, P., Ciais, P., Saunois, M., Canadell, J. G., Dlugokencky, E. J., Bergamaschi, P., Bergmann, D., Blake, D. R., Bruhwiler, L., Cameron-Smith, P., Castaldi, S., Chevallier, F., Feng, L., Fraser, A., Heimann, M., Hodson, E. L., Houweling, S., Josse, B., Fraser, P. J., Krummel, P. B., Lamarque, J.F., Langenfelds, R. L., Le Quéré, C., Naik, V., O’Doherty, S., Palmer, P. I., Pison, I., Plummer, D., Poulter, B., Prinn, R. G., Rigby, M., Ringeval, B., Santini, M., Schmidt, M., Shindell, D. T., Simpson, I. J., Spahni, R., Steele, L. P., Strode, S. A., Sudo, K., Szopa, S., van der Werf, G. R., Voulgarakis, A., van Weele, M., Weiss, R. F., Williams, J. E., and Zeng, G.: Three decades of global methane sources and sinks, Nat. Geosci., 6, 813-823, https://doi.org/10.1038/ngeo1955, 2013.

Klemedtsson, A. K. and Klemedtsson, L.: Methane uptake in Swedish forest soil in relation to liming and extra N-deposition, Biol. Fertil. Soils., 25, 296-301, https://doi.org/10.1007/s003740050318, 1997.

Lamarque, J.-F., Dentener, F., McConnell, J., Ro, C.-U., Shaw, M., Vet, R., Bergmann, D., Cameron-Smith, P., Dalsoren, S., Doherty, R., Faluvegi, G., Ghan, S. J., Josse, B., Lee, Y. H., MacKenzie, I. A., Plummer, D., Shindell, D. T., Skeie, R. B., Stevenson, D. S., Strode, S., Zeng, G., Curran, M., Dahl-Jensen, D., Das, S., Fritzsche, D., and Nolan, M.: Multi-model mean nitrogen and sulfur deposition from the Atmospheric Chemistry and Climate Model Intercomparison Project (ACCMIP): evaluation of historical and projected future changes, Atmos. Chem. Phys., 13, 7997-8018, https://doi.org/10.5194/acp-137997-2013, 2013.

Le Mer, J. and Roger, P.: Production, oxidation, emission and consumption of methane by soils: A review, Eur. J. Soil Biol., 37, 25-50, https://doi.org/10.1016/S1164-5563(01)01067-6, 2001.

Li, C., Aber, J., Stange, F., Butterbach-Bahl, K., and Papen, H.: A process-oriented model of $\mathrm{N}_{2} \mathrm{O}$ and $\mathrm{NO}$ emissions from forest soils: 1. Model development, J. Geophys. Res.-Atmos., 105, 4369-4384, https://doi.org/10.1029/1999JD900949, 2000.

Low, P. F., Hoekstra, P., and Anderson, D. M.: Some Thermodynamic Relationships for Soils at or Below the Freezing Point: 2. Effects of Temperature and Pressure on Unfrozen Soil Water, Water Resour. Res., 4, 541-544, https://doi.org/10.1029/WR004i003p00541, 1968.

Luo, G. J., Kiese, R., Wolf, B., and Butterbach-Bahl, K.: Effects of soil temperature and moisture on methane uptake and nitrous oxide emissions across three different ecosystem types, Biogeosciences, 10, 3205-3219, https://doi.org/10.5194/bg-103205-2013, 2013.

MacDonald, J. A., Skiba, U., Sheppard, L. J., Hargreaves, K. J., Smith, K. A., and Fowler, D.: Soil environmental variables affecting the flux of methane from a range of forest, moorland and agricultural soils, Biogeochemistry, 34, 113-132, https://doi.org/10.1007/BF00000898, 1996.

McLain, J. E. T. and Ahmann, D. M.: Increased moisture and methanogenesis contribute to reduced methane oxidation in elevated $\mathrm{CO}_{2}$ soils, Biol. Fertil. Soils, 44, 623-631, https://doi.org/10.1007/s00374-007-0246-2, 2007.

Mclain, J. E. T., Kepler, T. B., and Ahmann, D. M.: Belowground factors mediating changes in methane consumption in a forest 
soil under elevated $\mathrm{CO}_{2}$, Global Biogeochem. Cy., 16, 1050, https://doi.org/10.1029/2001GB001439, 2002.

Moldrup, P., Kruse, C. W., Rolston, D. E., and Yamaguchi, T.: Modelling diffusion and reaction in soils: III. Predicting gas diffusivity from the Campbell soil-water retention model, Soil Sci., 161, 366-375, 1996.

Moldrup, P., Deepagoda, T. K. K. C., Hamamoto, S., Komatsu, T., Kawamoto, K., Rolston, D. E., and de Jonge, L. W.: Structure-Dependent Water-Induced Linear Reduction Model for Predicting Gas Diffusivity and Tortuosity in Repacked and Intact Soil, Vadose Zone J., 12, 1-11, https://doi.org/10.2136/vzj2013.01.0026, 2013.

Mosier, A. R., Parton, W. J., Valentine, D. W., Ojima, D. S., Schimel, D. S., and Delgado, J. A.: $\mathrm{CH}_{4}$ and $\mathrm{N}_{2} \mathrm{O}$ fluxes in the Colorado shortgrass steppe: 1. Impact of landscape and nitrogen addition, Global Biogeochem. Cy., 10, 387-399, https://doi.org/10.1029/96GB01454, 1996.

Mosier, A. R., Morgan, J. A., King, J. Y., LeCain, D., and Milchunas, D. G.: Soil-atmosphere exchange of $\mathrm{CH}_{4}, \mathrm{CO}_{2}, \mathrm{NO}_{x}$, and $\mathrm{N}_{2} \mathrm{O}$ in the Colorado shortgrass steppe under elevated $\mathrm{CO}_{2}$, Plant Soil, 240, 201-211, https://doi.org/10.1023/A:1015783801324, 2002.

Myhre, G., Highwood, E. J., Shine, K. P., and Stordal, F.: New estimates of radiative forcing due to well mixed greenhouse gases, Geophys. Res. Lett., 25, 2715-2718, https://doi.org/10.1029/98GL01908, 1998.

Nishina, K., Ito, A., Hanasaki, N., and Hayashi, S.: Reconstruction of spatially detailed global map of $\mathrm{NH}_{4}^{+}$and $\mathrm{NO}_{3}^{-}$application in synthetic nitrogen fertilizer, Earth Syst. Sci. Data, 9, 149-162, https://doi.org/10.5194/essd-9-149-2017, 2017.

Oh, Y., Stackhouse, B., Lau, M. C. Y., Xu, X., Trugman, A. T., Moch, J., Onstott, T. C., Jørgensen, C. J., D'Imperio, L., Elberling, B., Emmerton, C. A., St. Louis, V. L., and Medvigy, D.: A scalable model for methane consumption in arctic mineral soils, Geophys. Res. Lett., 43, 5143-5150, https://doi.org/10.1002/2016GL069049, 2016.

Oremland, R. S. and Culbertson, C. W.: Importance of methaneoxidizing bacteria in the methane budget as revealed by the use of a specific inhibitor, Nature, 356, 421-423, https://doi.org/10.1038/356421a0, 1992.

Phillips, R. L., Whalen, S. C., Schlesinger, W. H.: Response of soil methanotrophic activity to carbon dioxide enrichment in a North Carolina coniferous forest, Soil Biol. Biochem., 33, 793-800, https://doi.org/10.1016/S0038-0717(00)00227-3, 2001.

Potter, C. S., Davidson, E. A., and Verchot, L. V.: Estimation of global biogeochemical controls and seasonality in soil methane consumption, Chemosphere, 32, 2219-2246, https://doi.org/10.1016/0045-6535(96)00119-1, 1996.

Prather, M. J., Holmes, C. D., and Hsu, J.: Reactive greenhouse gas scenarios: Systematic exploration of uncertainties and the role of atmospheric chemistry, Geophys. Res. Lett., 39, L09803, https://doi.org/10.1029/2012GL051440, 2012.

Priemé, A. and Christensen, S.: Seasonal and spatial variation of methane oxidation in a Danish spruce forest, Soil Biol. Biochem., 29, 1165-1172, https://doi.org/10.1016/S00380717(97)00038-2, 1997.

Ramankutty, N. and Foley, J. A.: Estimating historical changes in global land cover: Croplands from
1700 to 1992, Global Biogeochem. Cy., 13, 997-1027, https://doi.org/10.1029/1999GB900046, 1999.

Ridgwell, A. J., Marshall, S. J., and Gregson, K.: Consumption of atmospheric methane by soils: A processbased model, Global Biogeochem. Cy., 13, 59-70, https://doi.org/10.1029/1998GB900004, 1999.

Rigby, M., Prinn, R. G., Fraser, P. J., Simmonds, P. G., Langenfelds, R. L., Huang, J., Cunnold, D. M., Steele, L. P., Krummel, P. B., Weiss, R. F., O’Doherty, S., Salameh, P. K., Wang, H. J., Harth, C. M., Mühle, J., and Porter, L. W.: Renewed growth of atmospheric methane, Geophys. Res. Lett., 35, L22805, https://doi.org/10.1029/2008GL036037, 2008.

Rigler, E. and Zechmeister-Boltenstern, S.: Oxidation of ethylene and methane in forest soils-effect of $\mathrm{CO}_{2}$ and mineral nitrogen, Geoderma, 90, 147-159, https://doi.org/10.1016/S00167061(98)00099-8, 1999.

Rosenkranz, P., Brüggemann, N., Papen, H., Xu, Z., Horváth, L., and Butterbach-Bahl, K.: Soil $\mathrm{N}$ and $\mathrm{C}$ trace gas fluxes and microbial soil $\mathrm{N}$ turnover in a sessile oak (Quercus petraea (Matt.) Liebl.) forest in Hungary, Plant Soil, 286, 301-322, https://doi.org/10.1007/s11104-006-9045-z, 2006.

Sabrekov, A. F., Glagolev, M. V., Alekseychik, P. K., Smolentsev, B. A., Terentieva, I. E., Krivenok, L. A., and Maksyutov, S. S.: A process-based model of methane consumption by upland soils, Environ. Res. Lett., 11, 075001, https://doi.org/10.1088/17489326/11/7/075001, 2016.

Saggar, S., Hedley, C. B., Giltrap, D. L., and Lambie, S. M.: Measured and modelled estimates of nitrous oxide emission and methane consumption from a sheepgrazed pasture, Agric. Ecosyst. Environ, 122, 357-365, https://doi.org/10.1016/j.agee.2007.02.006, 2007.

Saunois, M., Bousquet, P., Poulter, B., Peregon, A., Ciais, P., Canadell, J. G., Dlugokencky, E. J., Etiope, G., Bastviken, D., Houweling, S., Janssens-Maenhout, G., Tubiello, F. N., Castaldi, S., Jackson, R. B., Alexe, M., Arora, V. K., Beerling, D. J., Bergamaschi, P., Blake, D. R., Brailsford, G., Brovkin, V., Bruhwiler, L., Crevoisier, C., Crill, P., Covey, K., Curry, C., Frankenberg, C., Gedney, N., Höglund-Isaksson, L., Ishizawa, M., Ito, A., Joos, F., Kim, H.-S., Kleinen, T., Krummel, P., Lamarque, J.-F., Langenfelds, R., Locatelli, R., Machida, T., Maksyutov, S., McDonald, K. C., Marshall, J., Melton, J. R., Morino, I., Naik, V., O’Doherty, S., Parmentier, F.-J. W., Patra, P. K., Peng, C., Peng, S., Peters, G. P., Pison, I., Prigent, C., Prinn, R., Ramonet, M., Riley, W. J., Saito, M., Santini, M., Schroeder, R., Simpson, I. J., Spahni, R., Steele, P., Takizawa, A., Thornton, B. F., Tian, H., Tohjima, Y., Viovy, N., Voulgarakis, A., van Weele, M., van der Werf, G. R., Weiss, R., Wiedinmyer, C., Wilton, D. J., Wiltshire, A., Worthy, D., Wunch, D., Xu, X., Yoshida, Y., Zhang, B., Zhang, Z., and Zhu, Q.: The global methane budget 2000-2012, Earth Syst. Sci. Data, 8, 697-751, https://doi.org/10.5194/essd-8-697-2016, 2016.

Saxton, K. E., Rawls, W. J., Romberger, J. S., and Papendick, R. I.: Estimating Generalized Soil-water Characteristics from Texture, Soil Sci. Soc. Am. J., 50, 1031, https://doi.org/10.2136/sssaj1986.03615995005000040039x, 1986.

Schnell, S. and King, G. M.: Mechanistic Analysis of Ammonium Inhibition of Atmospheric Methane Consumption in Forest Soils, Appl. Environ. Microbiol., 60, 3514-3521, 1994. 
Schnell, S. and King, G. M.: Responses of Methanotrophic Activity in Soils and Cultures to Water Stress, Appl. Environ. Microbiol., 62, 3203-3209, 1996.

Shangguan, W., Dai, Y., Duan, Q., Liu, B., and Yuan, H.: A global soil data set for earth system modelling, J. Adv. Model. Earth Syst., 6, 249-263, https://doi.org/10.1002/2013MS000293, 2014.

Singh, B. K., Bardgett, R. D., Smith, P., and Reay, D. S.: Microorganisms and climate change: terrestrial feedbacks and mitigation options, Nat. Rev. Microbiol., 8, 779-790, https://doi.org/10.1038/nrmicro2439, 2010.

Singh, J. S., Singh, S., Raghubanshi, A. S., Singh, S., Kashyap, A. K., and Reddy, V. S.: Effect of soil nitrogen, carbon and moisture on methane uptake by dry tropical forest soils, Plant Soil, 196, 115-121, https://doi.org/10.1023/A:1004233208325, 1997.

Sitaula, B. K., Hansen, S., Sitaula, J. I. B., and Bakken, L. R.: Methane oxidation potentials and fluxes in agricultural soil: Effects of fertilisation and soil compaction, Biogeochemistry, 48, 323-339, https://doi.org/10.1023/A:1006262404600, 2000.

Sitch, S., Friedlingstein, P., Gruber, N., Jones, S. D., MurrayTortarolo, G., Ahlström, A., Doney, S. C., Graven, H., Heinze, C., Huntingford, C., Levis, S., Levy, P. E., Lomas, M., Poulter, B., Viovy, N., Zaehle, S., Zeng, N., Arneth, A., Bonan, G., Bopp, L., Canadell, J. G., Chevallier, F., Ciais, P., Ellis, R., Gloor, M., Peylin, P., Piao, S. L., Le Quéré, C., Smith, B., Zhu, Z., and Myneni, R.: Recent trends and drivers of regional sources and sinks of carbon dioxide, Biogeosciences, 12, 653679, https://doi.org/10.5194/bg-12-653-2015, 2015.

Smith, K. A., Dobbie, K. E., Ball, B. C., Bakken, L. R., Sitaula, B. K., Hansen, S., Brumme, R., Borken, W., Christensen, S., Priemé, A., Fowler, D., Macdonald, J. A., Skiba, U., Klemedtsson, L., Kasimir-Klemedtsson, A., Degórska, A., and Orlanski, P.: Oxidation of atmospheric methane in Northern European soils, comparison with other ecosystems, and uncertainties in the global terrestrial sink, Global Change Biol., 6, 791-803, https://doi.org/10.1046/j.1365-2486.2000.00356.x, 2000.

Spahni, R., Wania, R., Neef, L., van Weele, M., Pison, I., Bousquet, P., Frankenberg, C., Foster, P. N., Joos, F., Prentice, I. C., and van Velthoven, P.: Constraining global methane emissions and uptake by ecosystems, Biogeosciences, 8, 1643-1665, https://doi.org/10.5194/bg-8-1643-2011, 2011.

Steinkamp, R., Butterbach-Bahl, K., and Papen, H.: Methane oxidation by soils of an $\mathrm{N}$ limited and $\mathrm{N}$ fertilized spruce forest in the Black Forest, Germany, Soil Biol. Biochem., 33, 145-153, https://doi.org/10.1016/S0038-0717(00)00124-3, 2001.

Tate, K. R., Ross, D. J., Saggar, S., Hedley, C. B., Dando, J., Singh, B. K., and Lambie, S. M.: Methane uptake in soils from Pinus radiata plantations, a reverting shrubland and adjacent pastures: Effects of land-use change, and soil texture, water and mineral nitrogen, Soil Biol. Biochem., 39, 1437-1449, https://doi.org/10.1016/j.soilbio.2007.01.005, 2007.

Ueyama, M., Takeuchi, R., Takahashi, Y., Ide, R., Ataka, M., Kosugi, Y., Takahashi, K., and Saigusa, N.: Methane uptake in a temperate forest soil using continuous closedchamber measurements, Agric. For. Meteorol., 213, 1-9, https://doi.org/10.1016/j.agrformet.2015.05.004, 2015.

van den Pol-van Dasselaar, P., van Beusichem, M. L., and Oenema, O.: Effects of soil moisture content and temperature on methane uptake by grasslands on sandy soils, Plant Soil, 204, 213-222, https://doi.org/10.1023/A:1004371309361, 1998.

Vecherskaya, M. S., Galchenko, D. V. F., Sokolova, E. N., and Samarkin, V. A.: Activity and species composition of aerobic methanotrophic communities in tundra soils, Curr. Microbiol., 27, 181-184, https://doi.org/10.1007/BF01576018, 2013.

Veldkamp, E., Weitz, A. M., and Keller, M.: Management effects on methane fluxes in humid tropical pasture soils, Soil Biol. Biochem., 33, 1493-1499, https://doi.org/10.1016/S00380717(01)00060-8, 2001.

Visvanathan, C., Pokhrel, D., Cheimchaisri, W., Hettiaratchi, J. P. A., and $\mathrm{Wu}$, J. S.: Methanotrophic activities in tropical landfill cover soils: effects of temperature, moisture content and methane concentration, Waste Manag. Res., 17, 313-323, https://doi.org/10.1034/j.1399-3070.1999.00052.x, 1999.

von Fischer, J. C., Butters, G., Duchateau, P. C., Thelwell, R. J., and Siller, R.: In situ measures of methanotroph activity in upland soils: A reaction-diffusion model and field observation of water stress, J. Geophys. Res.-Biogeo., 114, G01015, https://doi.org/10.1029/2008JG000731, 2009.

Wang, Y., Xue, M., Zheng, X., Ji, B., Du, R., and Wang, Y.: Effects of environmental factors on $\mathrm{N}_{2} \mathrm{O}$ emission from and $\mathrm{CH}_{4}$ uptake by the typical grasslands in the Inner Mongolia, Chemosphere, 58, 205-215, https://doi.org/10.1016/j.chemosphere.2004.04.043, 2005.

Wang, Z.-P. and Ineson, P.: Methane oxidation in a temperate coniferous forest soil: effects of inorganic N, Soil Biol. Biochem., 35, 427-433, https://doi.org/10.1016/S0038-0717(02)00294-8, 2003.

Wania, R., Ross, I., and Prentice, I. C.: Implementation and evaluation of a new methane model within a dynamic global vegetation model: LPJ-WHyMe v1.3.1, Geosci. Model Dev., 3, 565-584, https://doi.org/10.5194/gmd-3-565-2010, 2010.

West, A. E., Brooks, P. D., Fisk, M. C., Smith, L. K., Holland, E. A., Iii, C. H. J., Babcock, S., Lai, R. S., and Schmidt, S. K.: Landscape patterns of $\mathrm{CH}_{4}$ fluxes in an alpine tundra ecosystem, Biogeochemistry, 45, 243-264, https://doi.org/10.1023/A:1006130911046, 1999.

Whalen, S. C.: Influence of $\mathrm{N}$ and non- $\mathrm{N}$ salts on atmospheric methane oxidation by upland boreal forest and tundra soils, Biol. Fertil. Soils, 31, 279-287, https://doi.org/10.1007/s003740050657, 2000.

Whalen, S. C. and Reeburgh, W. S.: Moisture and temperature sensitivity of $\mathrm{CH}_{4}$ oxidation in boreal soils, Soil Biol. Biochem., 28, 1271-1281, https://doi.org/10.1016/S0038-0717(96)001393, 1996

Zhang, W., Mo, J., Zhou, G., Gundersen, P., Fang, Y., Lu, X., Zhang, T., and Dong, S.: Methane uptake responses to nitrogen deposition in three tropical forests in southern China, J. Geophys. Res.Atmos., 113, D11116, https://doi.org/10.1029/2007JD009195, 2008.

Zhuang, Q., Chen, M., Xu, K., Tang, J., Saikawa, E., Lu, Y., Melillo, J. M., Prinn, R. G., and McGuire, A. D.: Response of global soil consumption of atmospheric methane to changes in atmospheric climate and nitrogen deposition, Global Biogeochem. Cy., 27, 650-663, https://doi.org/10.1002/gbc.20057, 2013. 